\title{
Eiendomsmeglers plikt til å kontrollere og informere om kjøpers finansiering
}

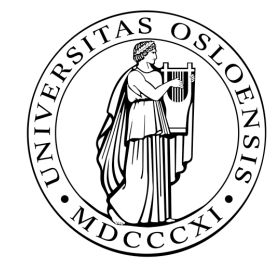

Universitetet i Oslo

Det juridiske fakultet

Kandidatnummer: 696

Leveringsfrist: 25.11.2009

Til sammen 17.906 ord

24.11.2009 


\section{Innholdsfortegnelse}

\section{INNLEDNING}

$\begin{array}{lll}1.1 & \text { Oppgavens tema og problemstilling } & 1\end{array}$

$\begin{array}{lll}1.2 & \text { Avgrensning } & 2\end{array}$

$\begin{array}{lll}1.3 & \text { Kort om rettskildebildet } & 3\end{array}$

1.4 Den videre fremstilling 5

$\underline{2}$ GJELDENDE RETT - EN GJENNOMGANG AV RETTSKILDENE

$\begin{array}{lll}2.1 & \text { Eiendomsmeglingsloven } & 6\end{array}$

$\begin{array}{lll}2.2 & \text { Forarbeider } & 7\end{array}$

2.3 Rettspraksis - Høyesterett 11

2.3.1 Rt. 1993 s. 156

2.4 Rettspraksis - Lagmannsrettene $\quad 14$

$\begin{array}{lll}2.4 .1 & \text { LB } 1996 \text { s. } 317 & 14\end{array}$

2.4.2 RG 2004 s. 552

$\begin{array}{lll}2.4 .3 & \text { RG } 2007 \text { s. } 1145 & 17\end{array}$

$\begin{array}{lll}2.4 .4 & \text { Oppsummering lagmannsrettene } & 17\end{array}$

$\begin{array}{lll}2.5 & \text { Rettspraksis - Tingrettene } & \mathbf{1 8}\end{array}$

$\begin{array}{lll}2.5 .1 & \text { Krystallen } & 18\end{array}$

2.6 Reklamasjonsnemnda for eiendomsmeglingstjenester 21

2.6.1 Utgangspunkt: kontrollplikt når det foreligger særlige omstendigheter 21

$\begin{array}{ll}\text { 2.6.2 Presiseringer av gjeldende rett } & 22\end{array}$

$\begin{array}{lll}2.6 .3 & \text { Oppsummering } & 24\end{array}$

$\begin{array}{lll}2.7 & \text { Disiplinærnemnden for advokater }\end{array}$ 
$\begin{array}{llr}2.9 & \text { Juridisk litteratur } & 26\end{array}$

$\begin{array}{lll}2.9 .1 & \text { Bråthen og Solli } & 27\end{array}$

$\begin{array}{lll}\text { 2.9.2 Rosén og Torsteinsen } & 27\end{array}$

$\begin{array}{llr}2.10 & \text { Bransjepraksis } & 28\end{array}$

2.11 Oppsummering av gjeldende rett - har megler plikt til å kontrollere og informere om kjøpers finansiering?

$\begin{array}{lll}3.1 & 31\end{array}$

$3.2 \quad$ Typen meglingsoppdrag $\quad 32$

3.2.1 Kort om ulike typer oppdrag og deres kjennetegn 32

$\begin{array}{lll}3.2 .2 & \text { Prosjektoppdrag } & 33\end{array}$

$\begin{array}{lll}3.3 & \text { Finansieringsmåte } & 35\end{array}$

3.3.1 Lånefinansiering $\quad 36$

$\begin{array}{lll}3.3 .2 & \text { Egenkapital } & 37\end{array}$

$\begin{array}{lll}3.3 .3 & \text { Videresalg av eksisterende bolig } & 39\end{array}$

$\begin{array}{lll}\text { 3.3.4 Videresalg før overtakelse i byggeprosjekter } & 40\end{array}$

3.4 Partene og deres profesjonalitet 44

$\begin{array}{lll}3.4 .1 & \text { Selger } & 42\end{array}$

$\begin{array}{lll}3.4 .2 & \text { Kjøper } & 43\end{array}$

3.5 Megler har fullmakt til å akseptere bud på vegne av selger 44

3.6 Forskuddsinnbetaling - mislighold 45

$\begin{array}{llr}3.7 & \text { Budskjema med finansieringsplan benyttes } & 47\end{array}$

$\begin{array}{llr}3.8 & \text { Eiendomsmeglers markedsforing } & 48\end{array}$

$\begin{array}{llr}3.9 & \text { Oppsummering særlige omstendigheter } & 48\end{array}$ 
$\begin{array}{lll}4.1 & \text { Innledning } & 51\end{array}$

4.2 Erstatning $\quad 51$

4.2.1 Ansvarsgrunnlag $\quad 52$

4.2.2 Økonomisk tap og årsakssammenheng $\quad 54$

$\begin{array}{lll}4.3 & \text { Nedsettelse av meglers vederlag } & 58\end{array}$

4.4 Oppsummering konsekvensene av pliktbrudd 59

$\underline{5}$ OPPSUMMERING

6 DOMS - OG AVGJØRELSESREGISTER

$\begin{array}{llr}6.1 & \text { Høyesterett } & 62\end{array}$

$\begin{array}{lll}6.2 & \text { Lagmannsrett } & 62\end{array}$

$\begin{array}{llr}6.3 & \text { Tingrett } & 62\end{array}$

$\begin{array}{lll}\text { 6.4 Reklamasjonsnemnda for eiendomsmeglingstjenester } & 62\end{array}$

$\begin{array}{lll}\text { 6.5 } & \text { Disiplinærnemnden for advokater }\end{array}$

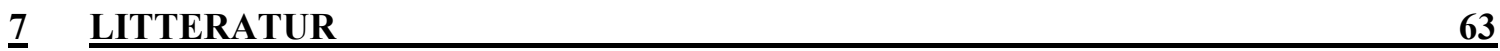

$\begin{array}{llr}7.1 & \text { Bøker } & 63\end{array}$

$\begin{array}{lll}7.2 & \text { Internettsider } & 64\end{array}$

$\underline{8}$ FORARBEID- OG LOVREGISTER

$\begin{array}{llr}8.1 & \text { Lover } & 64\end{array}$

$\begin{array}{llr}8.2 & \text { Forarbeider } & 64\end{array}$ 


\section{Innledning}

\subsection{Oppgavens tema og problemstilling}

Oppgavens tema er eiendomsmeglers plikter overfor oppdragsgiver (som oftest selger), også kalt meglers omsorgsplikt. Problemstillingen er om megler har plikt til å kontrollere og informere om kjøpers finansiering i forbindelse med eiendomssalg.

Reelle hensyn kan tale for og i mot en alminnelig kontroll- og informasjonsplikt. Forutberegnelighet, prevensjon og prosessøkonomiske hensyn taler for en generell plikt, mens effektivitet, kapasitet og praktiske hensyn taler mot en slik plikt.

Det kan være behov for kontroll og informasjon om kjøpers finansiering både før aksept av bud og ved kontraktsinngåelsen. Før aksept er en finansieringskontroll avgjørende for å vurdere hvor sikkert det er at kjøper kan betale. Jo sikrere finansieringen er, jo større sannsynlighet er det for at oppgjøret blir problemfritt. En kontroll ved avtaleinngåelsen er viktig for meglers rådgivning til selger. Ofte betales det et forskudd når avtalen inngås. Dersom denne forskuddsinnbetalingen uteblir kan en kontroll ved avtaleinngåelsen være retningsgivende for meglers rådgivning til selger om han bør fastholde avtalen.

Har ikke kjøper god nok finansiering kan det oppstå økonomisk tap for selger. I så tilfelle sitter selger igjen med en eiendom det har kostet penger å forsøke å selge. Et nytt salgsforsøk vil dessuten føre til ytterligere utgifter, i tillegg til en risiko for at eiendommen blir solgt til en lavere pris. Dersom megler har brutt en kontroll- og/eller informasjonsplikt kan det tenkes at han kan stilles ansvarlig for selgers tap.

I det følgende vurderes det om megler etter gjeldende rett har plikt til å undersøke og informere selger om kjøpers finansielle stilling. Det kartlegges hvilke særlige 
omstendigheter som kan tale for at megler har en slik plikt, og hva konsekvensene av pliktbrudd er.

\subsection{Avgrensning}

Oppgaven fokuserer på kjøp av boligeiendom. Det avgrenses derfor mot kjøp av næringseiendom og utleiemegling.

Meglers plikter knyttet til kjøpers finansiering vurderes i forhold til prosjektoppdrag, det vil si salg av ikke ferdigstilte boliger, og normalsituasjonen, som er salg av ferdigstilte boliger (både brukte og nye). Såkalte kjøpsoppdrag, hvor kjøper er meglers oppdragsgiver mot normalt selgeren, behandles ikke. Oppgaven ser på salg til og mellom forbrukere og/eller næringsdrivende. Det presiseres at selv om salg til eller fra næringsdrivende omfattes er det kun boligeiendom, og ikke næringseiendom, oppgaven behandler. Kjøp av eiendom gjennom salg av selskaper (som hovedsakelig eier eiendom) faller utenfor oppgaven.

Oppgaven drøfter ikke andre grunnlag for megleransvar enn at megler har unnlatt å kontrollere kjøpers finansiering. Drøftelsen skjer på bakgrunn av standarden om god meglerskikk. Hvorvidt det er uttrykkelig avtalt i oppdragsavtalen i et konkret tilfelle at megler skal kontrollere kjøpers finansiering vil derfor ikke ha betydning (i forbrukerforhold kan man avtale dette ettersom det er i favør av forbrukeren, her oppdragsgiveren. Man kan derimot ikke innskrenke meglers plikter etter eiendomsmeglingsloven i oppdragsavtalen).

Ettersom fokus i oppgaven er den delen av meglers plikter som skal ivareta oppdragsgiver, behandles ikke de plikter som skal ta hensyn til kjøperen. En aktuell problemstilling i denne sammenheng er om eiendomsmegler har frarådningsplikt overfor kjøper dersom megler må forstå at kjøper påtar seg en forpliktelse som vedkommende ikke er i stand til å håndtere. Problemet er særlig aktuelt ved salg av leiligheter i borettslag med høy fellesgjeld. Ifølge Komada-saken, LB-2009-11561, fra Borgarting lagmannsrett hadde ikke megler slik frarådingsplikt og megler hadde heller ikke brutt omsorgsplikten. Kjøper manglet helt grunnleggende kunnskaper om gjeld og renter, boliger og boligmarkedet, men dette var utenfor det megler med rimelighet kunne forvente, og det var ikke grunnlag for å rette bebreidelser mot ham. 
I gjennomgangen av rettskilder er det norsk rett som gjennomgås. Hvordan problemet er løst i utenlandsk rett bedømmes ikke.

\subsection{Kort om rettskildebildet}

Lov om eiendomsmegling av 29. juni 2007 nr. 73 (heretter eiendomsmeglingsloven eller eml.) er utgangspunktet for vurderingen av om eiendomsmegler har plikt til å kontrollere og informere om kjøpers finansiering. Hovedvekten legges på eiendomsmeglingsloven fra 2007 som trådte i kraft 1.januar 2008. Eiendomsmeglingsloven fra 1989 berøres også da loven fortsatt vil gjelde for eiendomsmegleroppdrag som ble inngitt før 1.januar 2008. Lovteksten i de to lovene er dessuten tilnærmet lik. Bakgrunnen og forståelsen av 1989loven kan derfor være til hjelp ved anvendelsen av den nye loven. De to første eiendomsmeglingslovene fra 1931 og 1938 har liten relevans da de gjelder oppdrag inngitt før 1989. Lovene vil derfor ikke omtales ytterligere.

Forarbeidene til eiendomsmeglingsloven fra 2007 er NOU 2006:1 og Ot.prp.nr. 16 (20062007), mens NOU 1987:14 og Ot.prp.nr. 59 (1988-1989) er forarbeidene til 1989-loven. I den grad spørsmålet om eiendomsmeglers plikt til å undersøke kjøpers finansiering er behandlet vil disse være av interesse.

Rettspraksis, særlig dommer fra Høyesterett, har relevans fordi avgjørelsene viser hvordan eiendomsmeglingsloven har blitt forstått i praksis. Avgjørelser fra Høyesterett, lagmannsretter og tingretter, som gjelder eiendomsmeglers plikt til å undersøke kjøpers finansiering, gjennomgås og drøftes nedenfor for å kartlegge hvordan gjeldende rett praktiseres.

Annen praksis av interesse er avgjørelser fra Reklamasjonsnemnda for eiendomsmeglingstjenester (heretter Reklamasjonsnemnda eller Nemnda). Nemnda ble etablert 1. januar 2005 gjennom avtale mellom Norges Eiendomsmeglingsforbund, Den norske Advokatforening, Eiendomsmeglingsforetakenes forening og Forbrukerrådet. Alle 
foretak eller advokater som driver eiendomsmegling skal i følge eml.§ 2-10 være tilsluttet en nemndsordning. Totalt er 877 medlemmer tilsluttet ${ }^{1}$.

Reklamasjonsnemnda er en særskilt nemnd som behandler klager fra privatpersoner på eiendomsmeglingsforetak eller advokater (som driver eiendomsmegling) for deres tjenesteutøvelse ${ }^{2}$. Klager kan være selger, kjøper eller øvrige interessenter og klagen kan angå alle sider ved utøvelsen av meglervirksomheten.

Nemnda har ikke domstolsstatus og avgjørelsene vil således ha mindre rettskildemessig vekt enn rettspraksis. Reklamasjonsnemndas uttalelser binder dessuten ikke partene da de kun er rådgivende. Nemndas praktisering av hva som ligger i god meglerskikk kan likevel ha betydning og gjennomgås derfor i oppgavens punkt 2.6. Dette gjelder kanskje særlig dersom det er mange like uttalelser i samme retning som partene har akseptert ved ikke å forfølge saken for domstolene. At det foreligger lite rettspraksis om spørsmålet om meglers plikt til å kontrollere kjøpers finansiering kan være et tegn på at Nemndas avgjørelser har blitt etterfulgt.

Dersom megler ikke vil etterkomme et nemndsvedtak som går i mot ham skal han gi en skriftlig begrunnet tilbakemelding til Nemnda innen tre uker. En megler som unnlater å følge Nemndas avgjørelse uten tilfredsstillende begrunnelse innrapporteres til Kredittilsynet som fører kontroll med at meglerforetak, advokater og boligbyggelag driver meglingen i samsvar med lover og forskrifter, herunder kravet om god meglerskikk. Under behandlingen i Reklamasjonsnemnda kan tvisten ikke bringes inn for domstolene, men realitetsbehandlingen hindrer ikke etterfølgende sivilt søksmål. En nemndsavgjørelse kan bringes direkte inn for tingretten uten behandling i forliksrådet.

Disiplinærnemnden for advokater er ankeinstans for beslutninger avsagt av foreningens disiplinærutvalg. Nemnden behandler, som disiplinærutvalgene, klager over brudd på god

${ }^{1}$ http://www.eiendomsmeglingsnemnda.no/index.gan?id=7\&subid=0 [28.10.2009]

${ }^{2}$ http://www.eiendomsmeglingsnemnda.no/index.gan?id=7\&subid=0 $[30.08 .2009]$ 
advokatskikk og salærklager mot medlemmer av Advokatforeningen ${ }^{3}$. Relevante beslutninger fra Disiplinærnemnden gjennomgås.

Det er flere forfattere som har skrevet om eiendomsmegling. Likevel er det få som har berørt spørsmålet om hvorvidt eiendomsmegler har plikt til å undersøke kjøpers finansiering. De synspunkter som fremkommer i juridisk teori om spørsmålet presenteres og vurderes.

Utarbeidede retningslinjer og bransjeskikk er relevant for å forstå hvordan bransjen har forstått og praktisert den relevante lovgivningen. Bransjepraksis vurderes i tillegg til de reelle hensyn som gjør seg gjeldende.

\subsection{Den videre fremstilling}

Oppgavens kapittel 2, om gjeldende rett, tar for seg hva som kan utledes av de ulike rettskildene når det gjelder eiendomsmeglers plikt til å kontrollere og informere om kjøpers finansielle stilling. I punkt 2.11 vurderes disse rettskildene for å fastslå hva som er gjeldende rett - om eiendomsmegler har en generell plikt til å kontrollere og informere om kjøpers finansiering eller ikke. I kapittel 3 drøftes det hvilke særlige omstendigheter som kan utgjøre momenter i en helhetsvurdering som taler for at megler har en kontroll- og informasjonsplikt. Kapittel 4 tar deretter for seg konsekvensene av at kontroll- og informasjonsplikten forsømmes, før kapittel 5 gir en oppsummering av oppgavens konklusjoner og en vurdering av dagens rettstilstand.

\footnotetext{
${ }^{3}$ www.advokatforeningen.no/Disiplinarsystemet/Disiplinar-og-tillitssystemet/ [16.11.2009]
} 


\section{Gjeldende rett - en gjennomgang av rettskildene}

\subsection{Eiendomsmeglingsloven}

Eiendomsmeglingsloven har ingen egen regel om finansieringskontroll av kjøpere. En eventuell plikt for megler til å kontrollere og informere om kjøpers finansiering må derfor utledes av lovens generelle prinsipp om god meglerskikk i $\S 6-3$. Bestemmelsen regulerer meglers omsorgsplikt overfor oppdragsgiveren. I 1989-loven følger prinsippet om god meglerskikk av § 3-1 og i gjeldende lov av § 6-3. Lovteksten i 1989-loven var som nevnt tilnærmet lik dagens lov og lyder som følger:

\section{"§ 3-1. Omsorgsplikt.}

(1)Megleren skal utføre oppdraget i samsvar med god meglerskikk, uten unødig opphold og med omsorg for begge parters interesser.

(2)Megleren skal gi kjøper og selger råd og opplysninger av betydning for handelen og gjennomføring av denne. "

Ordlyden i dagens eiendomsmeglingslov er slik:

\section{"§ 6-3. God meglerskikk}

(1)Oppdragstaker skal i sin virksomhetsutøvelse opptre i samsvar med god meglerskikk med omsorg for begge parters interesser. Oppdragstakeren må ikke opptre på noen måte som er egnet til å svekke tilliten til oppdragstakerens integritet og uavhengighet.

(2)Oppdragstakeren skal gi kjøper og selger råd og opplysninger av betydning for handelen og gjennomføringen av denne.

(3)Oppdragstakeren skal ikke inngå avtale om eiendomsmegling dersom inngåelse av slik avtale er satt som vilkår i avtale om annet enn eiendomsmegling.

(4)I forbindelse med eiendomsmeglingsoppdrag kan det ikke settes som vilkår at oppdragsgiveren inngår avtale om ytelser som ikke står i rimelig sammenheng med oppdraget." 
Den største endringen, i forhold til prinsippet om god meglerskikk, er at kravet om at utførelsen skal skje "uten unødig opphold" fra 1989-loven er falt bort i dagens lov. Bortsett fra dette må innholdet i god meglerskikk standarden forstås likt etter begge lovene. God meglerskikk er et vagt begrep og dets innhold kan variere etter forholdene. En alminnelig språklig forståelse av ordlyden i bestemmelsene gir derfor ikke svar på om eiendomsmegler har en plikt til å kontrollere og informere om kjøpers finansiering. Av den grunn må loven suppleres med andre rettskilder, for å få fastlagt om det i kravet til god meglerskikk i eml.§ 6-3 (tidligere § 3-1) ligger en plikt for megler til å undersøke kjøpers finansiering.

Eml.§ 6-7 inneholder regler om eiendomsmeglers opplysningsplikt overfor kjøper om faktiske og rettslige forhold knyttet til eiendommen som overdras. Derimot er ikke meglers opplysningsplikt overfor selger om forhold vedrørende kjøper, herunder kjøpers finansiering, direkte regulert i loven utover det som kan utledes av eml.§ 6-3. Årsaken til dette er, i følge forarbeidene ${ }^{4}$, at det eksisterer et avtaleforhold mellom selger som oppdragsgiver og megler. Loven kommer da i tillegg til avtalen. Oppdragsavtalen og den lojalitetsplikten som følger av generelle avtalerettslige prinsipper er derfor relevant når meglers plikter skal vurderes. Hvorvidt megler har påtatt seg å kontrollere finansieringen i oppdragsavtalen må imidlertid drøftes konkret, fordi hver oppdragsavtale vil inneholde individuelle bestemmelser om meglers plikter. Brudd på en plikt som er regulert i oppdragsavtalen kan være et særskilt grunnlag for krav mot megleren. Dette omtales imidlertid ikke ytterligere da det er god meglerskikk standarden i eiendomsmeglingsloven som er oppgavens fokus.

\subsection{Forarbeider}

Forarbeidene til 1989-loven innførte uttrykket "god meglerskikk" som erstatning for det tidligere kravet til "god forretningsskikk" i loven fra 1938 5. I følge Ot.prp.nr. 16 (20062007) er god meglerskikk en innarbeidet rettslig standard. Det vil si en rettsregel som viser til en vurderingsnorm utenfor seg selv som er avgjørende. Normen kan for eksempel være av moralsk eller sosial karakter. Man kan derfor tillegge bestemmelsen et innhold som gjenspeiler dagens alminnelige oppfatning av hva god meglerskikk er, og som er tilpasset den situasjonen man befinner seg $\mathrm{i}^{6}$. Ettersom den rettslige standarden om god meglerskikk

\footnotetext{
${ }^{4}$ Ot.prp.nr. 16 (2006-2007) s.160.

${ }^{5}$ Ot.prp.nr.16 (2006-2007) s.148.

${ }^{6}$ Jusleksikon (2007) s.273.
} 
er elastisk, vil en eventuell plikt til å kontrollere og informere om kjøpers finansielle stilling som utledes fra standarden, også kunne endres i takt med tiden og avhengig av den aktuelle situasjonen.

Praksis og oppfatninger i og utenfor eiendomsmeglerbransjen om hva som ligger i god meglerskikk vil supplere eiendomsmeglingsloven til enhver tid da begrepet som nevnt er en dynamisk rettslig standard. I forarbeidene til 1989-loven ${ }^{7}$ er det derimot understreket at bransjens egen standard ikke var avgjørende for det nærmere innholdet til god meglerskikk. Det avgjørende er en objektiv norm der hensynet til partene er fremtredende ${ }^{8}$ (med partene må forarbeidene sikte til partene i kjøpsavtalen, altså kjøper og selger). Forarbeidene fra 1989 utrykker videre at bransjepraksis likevel kan få betydning ved å føre til et strengere krav til meglerskikk enn det som følger av loven. Noe mildere krav begrunnet i bransjepraksis er ifølge forarbeidene derimot neppe aktuelt.

I forarbeidene til gjeldende eiendomsmeglingslov slutter departementet seg til lovutvalgets vurdering i NOU 2006:1 når det gjelder meglers plikt til å kontrollere og informere om kjøpers finansiering 9 . I NOUen henviser lovutvalget til Rt.1993 s.156 (dommen er behandlet i punkt 2.3.1) og slutter følgende ut fra dommen når det gjelder finansieringskontroll:

"Det er visse holdepunkter i rettspraksis og forvaltningspraksis for at megleren et stykke på vei må foreta visse undersøkelser knyttet til budgivernes finansiering." (det fremgår ikke hva slags forvaltningspraksis lovutvalget sikter til her)

I forhold til informasjonsplikt slutter utvalget som følger fra Høyesterettsdommen:

"Mye kan dessuten tale for at det kan være ansvarsbetingende av eiendomsmegler å anbefale et bud med usikker finansiering, uten å gjøre oppmerksom på usikkerheten.” Lovutvalget går et skritt videre fra disse slutningene i sin konklusjon etter en gjennomgang av bransjepraksis. I tillegg til de nevnte slutningene fra Høyesterettsdommen uttrykker utvalget også at undersøkelsesplikten kan skjerpes dersom megler har markedsført seg med at budgivers finansiering vil bli kontrollert.

\footnotetext{
${ }^{7}$ Ot.prp.nr. 59 (1988-1989).

${ }^{8}$ Ot.prp.nr.16 (2006-2007) s.148 og Ot.prp.nr. 59 (1988-1989) s. 20.

${ }^{9}$ Ot.prp.nr.16 (2006-2007) s. 149 (punkt 9.1.4).
} 
I sin gjennomgang av bransjepraksis fokuserer utvalget tydelig på normalsalgssituasjonen, hvor man ved budgivning vanligvis bruker budskjemaer med en finansieringsplan (kjøp som ikke skjer ved budrunder er typisk kjøp ved prosjektsalg hvor man ofte benytter prislister med faste priser og hvor først-til-mølla prinsippet gjelder). Lovutvalget fremstiller nemlig bransjepraksis slik at budgiver oppgir navnet på en kontaktperson i banken som kan bekrefte finansieringsplanen (man opphever da bankens taushetsplikt), eller ved at kjøper vedlegger et finansieringsbevis. Megler kontrollerer deretter budgivers finansiering, helst før selger aksepterer budet, ved å ringe budgivers oppgitte kontaktperson. Ifølge utvalget anses dette i bransjen som en bekreftelse på at kunden har økonomisk evne til å gjennomføre kjøpet. Utvalget uttaler seg likevel ikke hvorvidt dette anses som en tilfredsstillende finansieringskontroll eller i hvilke situasjoner megler anses å ha, eller ikke ha, plikt til å undersøke finansieringen på denne måten. NOUen gir derfor kun en presentasjon av hvordan kontrollen foregår i praksis uten noen nærmere vurdering av denne.

Til tross for manglende vurdering av om bransjens praksis for finansieringskontroll er tilfredsstillende, konkluderer lovutvalget med at det ikke er behov for å lovfeste noe uttrykkelig om eiendomsmeglers plikter. Begrunnelsen for dette er som følger:

"Etter utvalgets oppfatning tilsier meglers omsorgsplikt at budgiveres finansiering kontrolleres så langt det er mulig. Arbeidsbyrden med å gjøre dette er ikke stor sammenholdt med viktigheten av at finansieringen er i orden."

Utvalget ser her ut til å mene at meglers omsorgsplikt, og dermed god meglerskikk standarden, i seg selv utgjør et argument, jf. "tilsier", som taler for at megler kontrollerer finansieringen $i$ alle tilfeller. Det virker som utvalget mener at kun reelle hindringer er god nok grunn til å sette en kontrollplikt til side, slik at en kontroll også må foretas selv om det ikke foreligger konkrete holdepunkter for at finansieringen er usikker, jf. "budgivers finansiering kontrolleres så langt det er mulig”. Utvalget lar det med andre ord ikke være avgjørende for meglers eventuelle undersøkelsesplikt om finansieringen fremstår som usikker eller ikke. Utvalget går derfor lenger enn sin egen slutning fra Høyesterettsdommen 
som var at "megleren et stykke på vei må foreta visse undersøkelser knyttet til budgivernes finansiering".

I tillegg til dette konstaterer utvalget at dersom megler av ulike grunner ikke har fătt bekreftet budgivers finansieringsplan (til tross for forsøk på dette jf. "kontrolleres så langt det er mulig”), eller budgiveren ikke ønsker å underrette om dette, "skal selger informeres om dette". Megler pålegges tilsynelatende en informasjonsplikt når finansieringen er ubekreftet fordi utvalget mener at finansieringen er usikker i slike tilfeller. I følge forarbeidene skal megleren derfor alltid underrette selgeren dersom det er usikkerhet ved kjøpers finansiering, uansett om finansieringen er bekreftet eller ikke. Er finansieringen derimot kontrollert og i orden pålegger ikke forarbeidene megler noen informasjonsplikt.

Etter min oppfatning er det likevel fordelaktig at megler holder selger best mulig informert. Dersom megler etter en kontroll på en forsvarlig måte vurderer finansieringen som sikker, og ikke informerer selger om dette, vil ikke megler kunne holdes ansvarlig dersom finansieringen likevel ikke holder. Forarbeidene presiserer nemlig at selv om megler har fått bekreftet finansieringen er dette ingen garanti for at budgiver evner å finansiere kjøpet. Av den grunn vil det ikke være hensiktsmessig å pålegge megler noen informasjonsplikt når finansieringen er kontrollert og $\mathrm{i}$ orden.

Det er klart at forarbeidene med dette går lenger i å pålegge megler informasjonsplikt enn Høyesterett og hva de selv sluttet ut fra Høyesterettsdommen. Deres egen slutning var at mye kan "dessuten tale for at det kan være ansvarsbetingende av eiendomsmegler å anbefale et bud med usikker finansiering, uten å gjøre oppmerksom på usikkerheten”.

Forarbeidene gir etter min mening ikke et klart bilde av rettstilstanden. Lovutvalget ser imidlertid ut til å gå et skritt videre fra Høyesterettsdommen og sin slutning fra denne og forvaltningspraksis (det fremgår som nevnt ikke hva slags forvaltningspraksis lovutvalget sikter til). Det legges til grunn at god meglerskikk tilsier at finansieringen kontrolleres så langt det er mulig, samt at megler skal informere selger dersom finansieringen er usikker uavhengig av om den er bekreftet. Etter dette vil megler alltid ha en klar oppfordring til å kontrollere finansieringen hvor det er praktisk mulig, og selv om finansieringen fremstår 
som sikker. I tillegg må megler informere om eventuell usikkerhet. Forarbeidene fremhever også at meglers egen markedsføring kan tilsi en skjerpet undersøkelsesplikt for megleren.

Det ser etter dette ut til at forarbeidene åpner for en bevegelse av rettstilstanden i retning mot at megler etter hvert må sies å ha en generell plikt til å undersøke og informere om finansieringen dersom det er praktisk mulig. Man kan kanskje si at forarbeidene skisserer en viss plikt for megler til å undersøke og informere om kjøpers finansiering.

Det kan diskuteres om den rettstilstanden som materialiserer seg ut fra lovutvalgets uttalelser om eiendomsmeglers undersøkelsesplikt, er klar nok til at det ikke er behov for uttrykkelig lovregulering slik utvalget selv konkluderer. Forarbeidene gir ingen klar veiledning om megler har noen kontroll- og informasjonsplikt, og i så fall hvordan og i hvilket omfang finansieringskontrollen skal eller bør foregå. Hensynet til forutberegnelighet for oppdragsgiver, interessenter, oppdragsgivernes medkontrahent og meglerbransjen taler etter mitt syn for at lovpålagte krav til megler i stor grad følger uttrykkelig av loven.

\subsection{Rettspraksis - Høyesterett}

\subsubsection{Rt. 1993 s. 156}

Høyesterett har hittil bare berørt spørsmålet om eiendomsmeglers plikt til å undersøke kjøpers finansiering i én dom. I Rt.1993 s.156 uttaler Høyesterett i avdeling seg om temaet, til tross for at uttalelsene ikke var nødvendige for å begrunne resultatet i saken (såkalt obiter dictum ${ }^{10}$ ). Saken dreide seg egentlig om hvorvidt megleren hadde medvirket til å inngå en muntlig avtale om at selgeren skulle overlate en lunsjbar til kjøperen før kjøpesummen var betalt. En enstemmig Høyesterett kom til at megleren verken hadde medvirket til dette, eller til at det oppsto en uklar situasjon hvor dette skjedde, slik at

\footnotetext{
${ }^{10}$ Jusleksikon (2007) s.224.
} 
selgeren ble påført et tap. Når det gjaldt eiendomsmeglers plikt til å undersøke kjøpers finansiering uttalte Høyesterett følgende:

"Ankemotparten har videre anført at advokat Prøven forut for møtet 29 april opptrådte ansvarsbetingende ved ikke å undersøke Byes [Bye er selger. Dette antas å være en skrivefeil slik at det egentlig er snakk om Høiers finansiering her] finansiering eller ved ikke å meddele Bye at Høier avslo å dokumentere finansieringen. Som jeg kommer tilbake til, foreligger det etter min mening ikke årsakssammenheng mellom advokat Prøvens eventuelle uaktsomhet på dette punkt og det tap Bye krever erstattet. Foranlediget av prosedyren bemerker jeg imidlertid at spørsmålet må avgjøres med utgangspunkt i lovens alminnelige standard: hva god forretnings- eller meglerskikk tilsier. Forarbeidene til loven av 1938 gir ingen nærmere holdepunkter for bedømmelsen. Det samme gjelder forarbeidene til loven av 1989. Spørsmålet har etter det opplyste heller ikke vært fremme i rettspraksis.

I juridisk teori er det gitt uttrykk for at megleren ikke har en alminnelig undersøkelsesplikt, men at han, hvis det kan være grunn til å tvile på kjøperens betalingsevne, enten må iverksette nærmere undersøkelser eller i hvert fall gjøre selgeren kjent med den tvil som foreligger. Dette synes å angi en rimelig avgrensning av meglerens plikter. Hva som nærmere ligger i kravet til undersøkelser og hvorvidt megleren i alle tilfeller kan nøye seg med å gjøre sin tvil kjent for kjøperen, kan formodentlig være usikkert. Høyesterett har ikke fått seg forelagt opplysninger om hvorledes bransjen selv ser på meglerens undersøkelses- og opplysningsplikt når det gjelder kjøpers betalingsevne, og jeg går ikke nærmere inn på spørsmålene.”

Ettersom uttalelsene ikke var nødvendige for å begrunne resultatet blir vekten av disse mindre. I tillegg dreier dommen seg om næringsmegling som ikke behandles i oppgaven. På den annen side er dette den eneste dommen fra Høyesterett som berører meglers plikt til å kontrollere kjøpers finansiering. Uttalelsene om finansieringskontroll i dommen er dessuten referert til og brukt som utgangspunkt i etterfølgende avgjørelser fra lagmannsrettene, tingrettene, Reklamasjonsnemnda for eiendomsmeglingstjenester og i den nye eiendomsmeglingslovens forarbeider. Avgjørelsene som refererer til 
Høyesterettsdommen har dessuten ikke omhandlet næringsmegling. Dette viser at uttalelsene fra Høyesterett har blitt vektlagt i stor grad, til tross for at de ikke hadde avgjørende betydning i saken og selv om det for Høyesterett dreide seg om næringsmegling.

Høyesterett fastslår at spørsmålet ikke er berørt i rettspraksis og viser derfor til juridisk litteratur. Denne vurderes slik at den angir en rimelig avgrensning av meglers plikter. Det som fremgikk av litteraturen på domstidspunktet må derfor legges til grunn som Høyesteretts syn. Her slås det fast at megleren, når det er grunn til å tvile på kjøperens betalingsevne, "må iverksette nærmere undersøkelser". Noe krav om at undersøkelsene skal gi visse resultater kan ikke stilles ut fra denne formuleringen. Megler må med andre ord forsøke å kontrollere kjøpers finansiering jf. "iverksette". En kontroll som fører til at finansieringen forblir ubekreftet tilfredsstiller derfor kravet om iverksettelse av nærmere undersøkelser.

Til tross for at formuleringen "må" er brukt i dommen, kan det ikke sies å være en faktisk plikt for megleren. "Plikten" faller nemlig bort ifølge Høyesterett dersom megleren i stedet gjør selgeren kjent med den tvilen som foreligger, jf. "enten iverksetter ... eller i hvert fall gjør selgeren kjent med den tvil som foreligger" (min understrekning). Det er kanskje mer riktig å si at Høyesterett som et minstekrav, jf. "eller i hvert fall”, oppstiller en informasjonsplikt for megler dersom det foreligger tvil eller usikkerhet ved kjøpers betalingsevne. I dommen er det imidlertid noe usikkert om megleren i alle tilfeller kan nøye seg med å gjøre sin tvil kjent for kjøperen.

Høyesterett fremhever at det ikke er gitt opplysninger om bransjens syn på undersøkelser og informasjon om kjøpers finansiering. Dette viser at bransjepraksis er relevant ved vurderingen av eiendomsmeglers undersøkelsesplikt, selv om det følger av forarbeidene at bransjepraksis alene ikke er avgjørende. 
Høyesterett konkretiserer ikke hvilke særlige omstendigheter som typisk gir grunn til å tvile på kjøpers betalingsevne. Det sies heller ikke noe om innholdet i undersøkelsesplikten - hva de nærmere undersøkelser bør eller må bestå i. Likevel legger dommen opp til en rettstilstand hvor megler må iverksette nærmere undersøkelser når det er grunn til å tvile på kjøperens betalingsevne. Det er med andre ord en kontroll- og informasjonsplikt dersom særlige omstendigheter tilsier det. Høyesterett åpner imidlertid for at megler kanskje kan informere selger om usikkerhet ved kjøpers finansiering i stedet for å kontrollere denne. Informerer megler kan selger selv være i stand til å vurdere risikoen ved å akseptere selgers bud. Da er det mindre grunn til at megler skal ha risikoen for at kjøpers finansiering er i orden. Ettersom dommen kom 15 år før den nye eiendomsmeglingsloven trådte i kraft, må det som kan utledes av dommen ses i sammenheng med den etterfølgende utviklingen i rettstilstanden.

\subsection{Rettspraksis - Lagmannsrettene}

\subsubsection{LB 1996 s. 317}

I LB 1996 s. 317 ble en eiendomsmegler enstemmig frikjent for et erstatningskrav. Et av de anførte grunnlagene var manglende undersøkelse av kjøpers finansielle stilling. Når det gjaldt finansieringskontrollen uttalte retten følgende:

”Det antas at en eiendomsmegler i utgangspunktet ikke har plikt til å undersøke om en kjøper har oppgitt en realistisk finansieringsplan ved sin budgivning. Det må gjøres unntak dersom megleren er blitt kjent med forhold som gir grunn [til] større tvil enn vanlig med hensyn til om finansieringsplanen vil kunne gjennomføres. Da må megleren i det minste gjøre selgeren kjent med de omstendigheter som skaper tvilen.” Disse uttalelsene er i tråd med Høyesterettsdommen.

I denne saken hevdet selger at megler ikke foretok seg nok etter at det var klart at forskuddet ikke ble betalt i tide, og at en av kjøpers potensielle finansieringsinstitusjoner ikke kunne bistå med kjøpers finansiering. Retten la til grunn at forholdene ikke lå slik an at megler hadde noen grunn til å undersøke om kjøper ville være i stand til å betale 
kjøpesummen når det ble problemer med forskuddsbetalingen. Dette fordi alle parter visste at det var forutsatt at kjøpers eiendom var tenkt som finansieringskilde. Selger måtte derfor forstå at ettersom kjøper hadde problemer med forskuddsinnbetalingen ville han også ha problemer med å skaffe midlertidig finansiering for restkjøpesummen, hvis han ikke fikk solgt eiendommen som skulle tjene som finansiering før restkjøpesummen forfalt. Misligholdet ble tolket som et tegn på finansieringsproblemer for hele kjøpesummen. Megleren visste heller ikke om ytterligere forhold som tilsa at kjøpers eiendom likevel ikke kunne benyttes som finansiering, og hadde derfor ingen informasjon å gi. Det ble dessuten vektlagt at selger ikke uttrykkelig hadde bedt megler om å undersøke kjøpers finansiering $\mathrm{i}$ en slik situasjon.

Dommen pålegger kun megler å undersøke om kjøpers finansieringsplan er realistisk dersom det er grunn til å tvile på finansieringsplanens gjennomførbarhet. Dersom megler vet om forhold som skaper tvil om kjøpers finansiering, må han i det minste må gjøre selger kjent med dette. Dommen illustrerer også at manglende innbetaling av forskudd kan tilsi at megler må foreta nærmere undersøkelser av kjøpers finansiering, eller informere selger om den usikkerheten dette kan innebære. Megler må likevel ikke informere om forhold som selger allerede har kjennskap til, selv om dette er forhold som tilsier at kjøper har finansieringsproblemer.

\subsubsection{RG 2004 s. 552}

I denne dommen fra Gulating Lagmannsrett ble en eiendomsmegler enstemmig frikjent, men med dissens i forhold til begrunnelsen, for et erstatningskrav etter et dekningssalg. På avtaletidspunktet var ikke kjøper i stand til å foreta oppgjør fordi han var avhengig av betaling for en eiendomstransaksjon i Nederland. Dette visste selgerne.

Flertallet la til grunn at megler ikke har plikt til å undersøke kjøpers finansiering dersom ikke særlige forhold tilsier det. De uttalte også at megler ikke må utelate vesentlige opplysninger som selger trenger for sin vurdering, og at de opplysninger megler plikter å gi, vil avhenge av hvilken informasjon som er mulig å fremskaffe om den enkelte 
budgivers finansielle situasjon. Hovedbegrunnelsen for ansvarsfrihet var at selgerne selv hadde vært villige til å akseptere risikoen ved kjøpers betalingsevne da de satt på samme informasjon som megler. Flertallets begrunnelse samsvarer med tidligere rettspraksis. Flertallet mente også at det ikke var mulig å undersøke kjøpers betalingsevne nærmere her, eller mulighetene for å få en bankgaranti (som kjøper hadde lovet å fremlegge) på avtaletidspunktet. Dessuten kunne det etter flertallets syn ikke normalt stilles krav om bankgarantier i forbindelse med ordinære huskjøp.

Mindretallet mente derimot at det ikke forelå økonomisk tap og tok derfor ikke stilling til om megler hadde opptrådt erstatningsbetingende uaktsomt. De bemerket likevel at "megleren hadde en klar oppfordring til å foreta nærmere undersøkelser for å avklare kjøpers soliditet og til å redegjøre overfor selgerne om hvilke risiko som forelå og komme med råd i den forbindelse". Dette fordi kjøper ikke hadde bosted, formue, bankforbindelse eller inntekt i Norge. Mindretallet mente derfor det var grunn til å kritisere megler for manglende undersøkelser og rådgivning overfor selgerne.

Dommen viser, i likhet med LB 1996 s. 317, at når selgerne sitter med positiv kunnskap om kjøpers finansieringsmåte, er de i stand til å vurdere risikoen ved finansieringen på egenhånd. Dette betyr at megleren i disse tilfellene ikke må undersøke kjøpers finansielle stilling ytterligere. Han må heller ikke informere selger om kjøpers finansiering, og eventuelt den risiko usikkerheten ved finansieringen innebærer.

Retten omtaler på generelt grunnlag at hvilke opplysninger megler plikter å gi, vil avhenge av hvilken informasjon som er mulig å fremskaffe om den enkelte budgivers finansielle stilling. Det følger også av dommen at det ikke normalt kan kreves bankgaranti ved vanlig boligkjøp. Mindretallets begrunnelse bør også bemerkes. Dersom kjøper ikke har bosted, formue, bankforbindelse eller inntekt i Norge, kan det være et argument for at megler bør foreta en kontroll av kjøpers finansiering. 


\subsubsection{RG 2007 s. 1145}

I RG 2007 s.1145, fra Borgarting lagmannsrett, ble en megler enstemmig pålagt erstatningsansvar for tapet ved et dekningssalg. Retten fastslo, i tråd med Høyesterettsdommen, at det ligger utenfor meglers omsorgsplikt å undersøke finansieringen med mindre det foreligger særlige omstendigheter som tilsier noe annet. Retten vurderte meglers markedsføring, men den tilsa ikke at megler skulle ha kontrollert finansieringen. Årsaken til erstatningsansvaret var at megler ikke hadde kontrollert kjøpers finansiering etter at kjøperen misligholdt kontantdelen av kjøpesummen (forskuddet). Dersom megler hadde kontrollert finansieringen kunne han brukt informasjonen etter kontrollen, i tillegg til vissheten om misligholdet, og rådet selger til å fastholde kontrakten og gi kjøper ny betalingsfrist.

I følge dommen tilsier mislighold med forskuddsbetaling at megler skal sjekke kjøpers finansiering, fordi det kan føre til at selgers tap kan unngås eller reduseres betydelig. At finansieringen ikke blir sjekket kan derfor påvirke meglers rådgivning til selger. Selv om det ikke var utslagsgivende, illustrerer dommen også at meglers markedsføring kan tilsi at han har påtatt seg å undersøke kjøpers finansiering.

\subsubsection{Oppsummering lagmannsrettene}

Megler ble pålagt ansvar i én av tre dommer fra lagmannsrettene. Alle avgjørelsene legger til grunn Høyesteretts utgangspunkt om at megler ikke har noen generell plikt til å undersøke kjøpers finansiering, men at særlige omstendigheter kan tilsi det motsatte. Av LB 1996 s. 317 fremgår det at megleren, i stedet for å foreta en nærmere kontroll, kan informere selger om den usikkerheten som foreligger. Dette samsvarer delvis med Høyesterettsdommen. Både LB 1996 s. 317 og RG 2004 s. 552 slår fast at dersom selger allerede sitter på samme informasjon som megler om kjøpers finansiering, er han selv i stand til å vurdere risikoen ved finansieringen. Megler kan da ikke holdes ansvarlig for et eventuelt tap fordi han ikke har informert selger om usikkerheten. Har derimot megler ytterligere informasjon som tilsier at finansieringen er usikker, må han videreformidle dette 
til selger. I RG 2004 s. 552 stadfestes det at hvilken informasjon megler plikter å gi, vil avhenge av hvilken informasjon som er praktisk mulig å fremskaffe.

Lagmannsrettene har identifisert enkelte omstendigheter som i det enkelte tilfelle kan tilsi at megler må kontrollere og informere om kjøpers finansiering. En slik omstendighet kan være at forskuddsinnbetalingen er misligholdt. Kontrolleres finansieringen på misligholdstidspunktet kan det nemlig påvirke hvilke råd megler bør gi selger i en misligholdssituasjon. Lagmannsrettpraksis viser også at meglers markedsføring kan tilsi at han har påtatt seg å kontrollere finansieringen. Mindretallet i RG 2004 s. 552 fremholdt dessuten at dersom kjøperen har alle sine finansieringsmuligheter i utlandet innebærer det at megler bør foreta ytterligere kontroll. Når det gjelder kontrollens omfang konstateres det at meglers kontrollplikt ikke omfatter å undersøke kjøpers mulighet til å fremskaffe bankgaranti ved ordinære huskjøp, selv om det er avtalt at kjøper skal stille slik garanti.

\subsection{Rettspraksis - Tingrettene}

\subsubsection{Krystallen}

Dom fra Oslo tingrett av 8.januar $2009^{11}$ (heretter Krystallen) gjaldt hovedsakelig et erstatningskrav fra Krystallen AS (utbygger) mot eiendomsmeglingsforetaket Poppe \& Co Eiendomsmegling AS i forbindelse med salg av 5 leiligheter under oppføring i eiendomsprosjektet Krystallen på Kvitfjell. Avgjørelsen er anket og er derfor ikke rettskraftig ${ }^{12}$.

Eiendomsmegleren ble pålagt erstatningsansvar av tingretten for ikke å ha kontrollert kjøpernes finansiering ved kontraktsinngåelsen. Retten mente at megleren, etter en bestemmelse i rammeavtalen mellom utbygger og megler, var pålagt å kontrollere den enkelte kjøpers finansiering eller eventuelt opplyse om den tvil som måtte hefte ved denne.

\footnotetext{
${ }^{11}$ Saksnummer 08-090682TVI-OTIR/05.

${ }^{12}$ Anken er berammet for Borgarting lagmannsrett 08.12-16.12.2009.
} 
Til tross for at det ble nevnt i partenes anførsler, tok retten ikke stilling til om plikten etter avtalen gikk lenger enn det som følger av god meglerskikk standarden i eiendomsmeglingsloven. Likevel mener jeg at premissene i dommen er egnet til å kaste lys over forståelsen av standarden om god meglerskikk. Dette fordi avtalebestemmelsen om finansieringskontroll etter min vurdering ikke går lenger enn det som allerede følger av forarbeidene og bransjepraksis ${ }^{13}$.

Den aktuelle bestemmelsen i rammeavtalen lød som følger: 'P\&N [Poppe \& Nordvik] skal inngå kontrakt med kjøpere og sjekke at kjøpers finansiering er avklart. Nødvendig dokumentbehandling inngår”. Rettens oppfatning var at selv om bransjepraksis ifølge avtalen supplerte kontrakten, kunne det ikke forstås som en innskrenkning av avtalebestemmelsen. Selv om finansieringen besto i videresalg før overtakelse, og slik sett var "avklart", mente retten at megler likevel måtte sjekke at kjøper var betalingsdyktig på avtaletidspunktet. Tingretten mente også det var naturlig at megler påtok seg å sjekke finansieringen når han hadde fullmakt til å akseptere bud.

Omfanget av kontrollen var i følge retten avhengig av risikomomentene knyttet til den enkelte transaksjon. Retten uttalte at risikoen for at kjøpernes finansieringsevne svekkes, er større jo lenger tid det går fra avtale inngås til overtakelse finner sted. Av den grunn mente tingretten at det er av betydning å kontrollere kjøpernes betalingsevne, eventuelt økonomiske soliditet, på avtaletidspunktet for å redusere risikoen for at kjøper ikke kunne gjøre opp for seg ved overtakelse. Retten krevde ikke at megler innhenter bankgarantier eller finansieringsbevis, men at det kontrolleres at kjøper har en realistisk betalingsplan og eventuelt at kjøpers økonomiske soliditet kontrolleres. I LB 1996 s. 317 ble det derimot ikke stilt krav om at megler kontrollerte at kjøpers betalingsplan var realistisk dersom ikke det var større tvil enn vanlig ved finansieringsplanen. Tingretten mente også at megler plikter å informere selger om eventuell tvil ved finansieringen. Erstatningsansvaret ble pålagt til tross for at megleren mente at man ikke kunne sjekke finansieringen når det ble

\footnotetext{
${ }^{13}$ Se punkt 2.2 om forarbeider og punkt 2.10 om bransjepraksis.
} 
solgt leiligheter til investorer som baserte finansieringen på videresalg før overtakelse, at salgene skjedde under tidspress og at overtakelsen var flere år frem i tid, slik at en kontroll på avtaletidspunktet ikke ville ha noen verdi.

Dommen er den siste i rekken av rettspraksis om meglers plikt til å undersøke kjøpers finansiering. Samtidig er det den første dommen om finansieringskontroll etter den nye eiendomsmeglingsloven trådte i kraft. Dette forsterker dommens betydning. På den annen side dreier avgjørelsen seg om prosjektsalg i motsetning til annen gjennomgått rettspraksis. Da det kan være forskjeller mellom de ulike formene for salg, kan man ikke ukritisk bruke det retten legger til grunn i normalsalgstilfellene. De omstendigheter som påpekes av retten må imidlertid anses å være overførbare til normalsalgstilfellene. Til tross for at dommen ikke vurderer meglers plikt etter standarden om god meglerskikk i eiendomsmeglingsloven mener jeg likevel at dommens premisser kan ha en viss overføringsverdi.

I forhold til tidligere gjennomgåtte rettskilder er det nytt at retten pålegger megler å kontrollere at kjøper har en realistisk betalingsplan, jf. LB 1996 s. 317. I tillegg må eventuelt kjøpers økonomiske soliditet kontrolleres. Retten mente også at megler har plikt til å informere selger om eventuell tvil ved finansieringen. Dette samsvarer med forarbeidene. Retten legger også noe nytt til grunn ved at omfanget av meglers finansieringskontroll beror på risikomomentene i den enkelte eiendomstransaksjon. I følge retten, er det større risiko jo lenger tid det er mellom kontraktsinngåelsen og overtakelsen (i denne saken 2 år). Retten oppstilte, i tråd med RG 2004 s. 552, ikke noe krav om at megler innhenter avtalte bankgarantier, og finansieringsbevis kan heller ikke kreves. Dette må antas å være momenter som er anvendbare når man vurderer ansvar etter standarden om god meglerskikk selv om det aktuelle tilfellet ikke er et prosjektsalg. Dommen er ikke rettskraftig. Det som kan utledes av den kan derfor ikke tillegges særlig vekt før lagmannsretten har behandlet saken. 


\subsection{Reklamasjonsnemnda for eiendomsmeglingstjenester ${ }^{14}$}

Som vi har sett hittil er det ikke mye rettspraksis om meglers plikt til å undersøke kjøpers finansiering. Dette kan, som nevnt under punkt 1.3, forsterke betydningen av Nemndas uttalelser fordi det kan være et tegn på at avgjørelsene stort sett har blitt etterfulgt av begge parter. Nemndas praksis kan med det se ut til å gjenspeile bransjens og forbrukernes oppfatning av gjeldende rett.

\subsubsection{Utgangspunkt: kontrollplikt når det foreligger særlige omstendigheter} Reklamasjonsnemnda har i totalt 19 saker $^{15}$ i ulik grad berørt spørsmålet om meglers plikt til å undersøke kjøpers finansiering. Megler ble ikke pålagt ansvar i noen av sakene på grunnlag av manglende kontroll av finansieringen. Etter en gjennomgang av sakene er det klart at Reklamasjonsnemnda legger til grunn samme utgangspunkt som Høyesterett megler har ikke noen alminnelig plikt til å kontrollere og informere om kjøpers finansiering. Dette følger av en rekke av sakene som er gjennomgått ${ }^{16}$. Likevel følger det av nemndspraksis, i tråd med Høyesterett, at megler må undersøke og informere om finansieringen dersom det er forhold som indikerer at kjøper har dårlig betalingsevne. En avgjørelse legger til grunn at megler i stedet for kontroll kan informere om risikoen ved kjøpers finansielle stilling ${ }^{17}$. I tillegg til informasjon om forventet betalingsmislighold skal megler informere om betalingsmislighold som har skjedd ${ }^{18}$. Det må etter dette antas at megler på generelt grunnlag må informere om risikoen for betalingsmislighold. Sitter

\footnotetext{
${ }^{14}$ http://www.eiendomsmeglingsnemnda.no/index.gan?id=7\&subid=0 [30.08.2009]

${ }^{15}$ Reklamasjonsnemnda 1994/63, 1997/16, 1999/8, 2000/100, 2001/75, 2002/44, 2003/126, 2003/138, 2004/82, 2005/19, 2005/122, 2005/124, 2006/343, 2007/102, 2008/81, 2008/109, 2008/147, 2008/188, 2009/7 per 16.11.2009.

${ }^{16}$ Reklamasjonsnemnda 1994/63, 1997/16 (indirekte), 1999/8, 2000/100, 2001/75 (indirekte), 2002/44, 2003/126, 2003/138, 2005/124, 2007/102, 2008/81, 2008/109 og 2009/7.

${ }^{17}$ Reklamasjonsnemnda 2005/124.

${ }^{18}$ Reklamasjonsnemnda 2001/75, 2004/82, 2005/124, 2006/343, 2008/147, og 2008/188.
} 
selger allerede på den relevante informasjonen, trenger derimot ikke megleren å underrette selgeren ytterligere ${ }^{19}$.

Et forhold som kan indikere at megler har en plikt til å kontrollere finansieringen, kan være manglende innbetaling av avtalt forskudd ${ }^{20}$.

Det motsatte ble derimot uttalt av flertallet i en tidligere avgjørelse ${ }^{21}$ i strid med rettspraksis: "Flertallet er for øvrig også tilbøyelig til å være enig med innklagede i at forsinket innbetaling av kontantbeløp [forskuddet] sjelden er noe signal om alvorlige problemer med finansieringen av kjøpet”.

Meglers markedsføring er et annet forhold som etter Nemndas praksis kan tilsi at megler har påtatt seg å sjekke finansieringen ${ }^{22}$.

\subsubsection{Presiseringer av gjeldende rett}

Reklamasjonsnemnda presiserer utgangspunktet om at megler ikke har noen alminnelig undersøkelsesplikt dersom ikke særlige forhold tilsier det, og trekker med dette enkelte nye linjer i forhold til tidligere rettspraksis og forarbeidene.

Nemndas avgjørelser viser at det har skjedd en utvikling i bransjepraksis ved at det $\mathrm{i}$ bransjen er vanlig at kjøpers finansiering kontrolleres ${ }^{23}$. Dette er en videreutvikling fra Høyesterettsdommen som samsvarer med forarbeidenes presentasjon av bransjepraksis.

Når det gjelder omfanget av finansieringskontrollen kom Reklamasjonsnemnda med en tilsynelatende viktig uttalelse 2000/100. Nemnda uttrykte at "... det ikke kan utelukkes at utviklingen vil gå retning av [en] mer omfattende plikt for megleren til å kontrollere

\footnotetext{
${ }^{19}$ Reklamasjonsnemnda 2005/124.

${ }^{20}$ Reklamasjonsnemnda 2001/75 og 2009/7.

${ }^{21}$ Reklamasjonsnemnda 1999/8.

${ }^{22}$ Reklamasjonsnemnda 2000/100.

${ }^{23}$ Reklamasjonsnemnda 1999/8, 2000/100, 2002/44.
} 
kjøpers finansiering - herunder opplysninger om bankinnskudd og lignende - før aksept av bud, i hvert fall i bolighandelen". Tross dette har det ikke kommet senere uttalelser som utvider plikten som antatt. Nemnda har derimot senere lagt til grunn at det normalt ikke kreves at egenkapital kontrolleres dersom dette oppgis å være finansieringskilden ${ }^{24}$. Nemnda fastslo også (før forarbeidene til den nye loven) at det er tilstrekkelig å kontakte bankens saksbehandler, og få en muntlig bekreftelse fra denne, for å kontrollere budgivers opplysninger om lånetilsagn eller lånemuligheter ${ }^{25}$. Dette samsvarer med forarbeidenes presentasjon av bransjepraksis.

Får megler en muntlig bekreftelse per telefon har ikke megler grunn til å få mistanke om svindel eller lignende selv om han har fătt et mobilnummer til bankens saksbehandler ${ }^{26}$.

Finansieringsbevis gir etter Nemndas oppfatning megler tilstrekkelig informasjon om kjøpers finansiering ${ }^{27}$, men det oppstilles ingen plikt for megler til å fremskaffe slike, og dette representerer derfor heller ingen utvidelse fra utgangspunktet (at finansieringsbevis er tilstrekkelig må være åpenbart, da dette er en skriftlig bekreftelse fra banken og dermed en sterkere sikkerhet for at finansieringen er i orden enn en muntlig bekreftet finansieringsplan).

Reklamasjonsnemnda presiserer (som forarbeidene) at selv om megler under gitte omstendigheter må foreta nærmere undersøkelser, er han likevel ikke ansvarlig for at kjøpers finansiering til syvende og sist viser seg å holde mål ${ }^{28}$. Dersom en bekreftet finansiering eller et finansieringsbevis senere bortfaller eller trekkes tilbake, er megleren ikke ansvarlig ${ }^{29}$. Megler har heller ikke plikt til å forestå inndrivelse av kjøpesummen på

\footnotetext{
${ }^{24}$ Reklamasjonsnemnda 2004/82.

${ }^{25}$ Reklamasjonsnemnda 2001/75, 2002/44, 2003/75 og 2004/82.

${ }^{26}$ Reklamasjonsnemnda 2005/19.

${ }^{27}$ Reklamasjonsnemnda 2006/343.

${ }^{28}$ Reklamasjonsnemnda 2005/122, 2005/124 og 2008/81.

${ }^{29}$ Reklamasjonsnemnda 2002/44, 2005/122, 2006/343 og 2008/81.
} 
vegne av selgeren ${ }^{30}$. Manglende dokumentasjon på finansieringen medfører dessuten ikke at en allerede gitt aksept kan trekkes tilbake av selger ${ }^{31}$.

En "nyvinning" er Reklamasjonsnemndas synspunkt om at mye taler for at megler bør søke å sikre selgerens interesser gjennom et forskudd, ved å innarbeide krav om forskuddsbetaling i kjøpskontrakten mellom partene. Omstendighetene "...kan imidlertid variere på en slik måte at det ikke kan kreves at eiendomsmegler har noen slik forpliktelse, ${ }^{, 32}$.

\subsubsection{Oppsummering}

Betydningen av Nemndas praksis forsterkes ved at det er flere uttalelser som trekker i samme retning, og som partene har akseptert ved ikke å gå til søksmål i etterkant. Dette fører også til mindre rettspraksis om spørsmålet, som igjen bidrar til at Reklamasjonsnemndas praksis veier tyngre.

Utgangspunktet i Reklamasjonsnemndas praksis følger Høyesterettsdommen om at det kun er en plikt for megler til å kontrollere kjøpers finansielle stilling dersom særlige omstendigheter tilsier det. I tråd med lagmannsrettspraksis legges det til grunn at misligholdt forskuddsbetaling og meglers markedsføring kan tilsi at megler må undersøke finansieringen.

Nemnda kommer også med en del presiseringer som bidrar til en viss videreutvikling av rettstilstanden. Blant annet fremgår det at finansieringen vanligvis kontrolleres. Det er i følge Nemnda likevel ikke noe krav om at egenkapital kontrolleres, og heller ikke at skriftlig finansieringsbevis fremlegges. Dette kan sies å være i samsvar med forarbeidenes presentasjon av bransjens praksis hvor muntlig bekreftelse av finansieringen aksepteres.

\footnotetext{
${ }^{30}$ Reklamasjonsnemnda 2008/147.

${ }^{31}$ Reklamasjonsnemnda 1997/16.

${ }^{32}$ Reklamasjonsnemnda 2005/19.
} 
Reklamasjonsnemndas uttaler også at selgers interesser bør sikres gjennom et forskudd (som er regulert i avtaleforholdet mellom kjøper og selger).

\subsection{Disiplinærnemnden for advokater}

I ADA-2006-D103 fastslo Disiplinærnemnden for advokater at en advokat hadde brutt kravet om god meglerskikk grunnet en kritikkverdig unnlatelse av å kontrollere kjøpers finansiering. Nemnda tok ikke stilling til om unnlatelsen var så uaktsom at den kunne føre til erstatningsansvar. Det var flere forhold som tilsa at megler skulle drøftet kjøpers betalingsevne med selgeren.

Megler skulle ha informert selger om de problemer som kunne oppstå ved at kjøper i sin helhet skulle finansiere kjøpet med midler skaffet fra utlandet. Dette burde megler gjort før kontraktsinngåelsen, særlig ettersom kjøperne skulle betale mindre enn $10 \%$ i forskudd og dette skulle betales etter kontraktsinngåelsen. Selgerne ble ikke gjort oppmerksomme på den risikoen de påtok seg ved å undertegne kontrakten før forskuddet ble innbetalt, og før kontaktpersonene for finansieringen var oppgitt. At kjøper i kontrakten skulle endres, fra å lyde på en privatperson til å lyde på et selskap, tilsa også at megler burde ha foretatt nærmere undersøkelser av selskapet og dets betalingsevne.

\subsection{Reelle hensyn - Argumenter for og imot en plikt for megler}

Et argument som taler for at megler bør ha en plikt til å kontrollere og informere om kjøpers finansiering er forutberegnelighet for oppdragsgiver og interessenter. Oppdragsgiverens største interesse er å få oppgjør når avtale har kommet i stand. Kontrollerer og informerer megler om kjøpers finansiering har megler og/eller selger best mulig forutsetning for å vurdere sannsynligheten for oppgjør og dermed velge det budet med den sikreste finansieringen. Velges det sikreste budet, bidrar det til færre oppgjørsproblemer. For interessenter vil en plikt for megler til finansieringskontroll og informasjon innebære en oppfordring til å skaffe seg best mulig dokumentasjon for sin 
egen finansiering. Dette fordi man stiller sterkere i konkurranse med andre potensielle kjøpere.

En plikt for megler til å kontrollere og informere om kjøpers finansielle stilling vil være prosessøkonomisk gunstig. Kontroll vil bidra til færre konflikter slik at man unngår bruk av rettssystemet. Undersøkelser og informasjon om kjøpers finansielle stilling bidrar dessuten til tryggere eiendomshandel. Kontrollen gjør nemlig at man unngår risikofulle transaksjoner hvor kjøperen har dårlig betalingsevne.

Et argument som taler mot en plikt til finansieringskontroll og informasjon er hensynet til meglers arbeidsmengde og effektivitet. Det kan også være praktisk vanskelig, og kanskje til og med umulig for megler, å gjennomføre en kontroll av kjøpers finansiering i en del tilfelle. Da kan det virke urimelig at megler kan pålegges ansvar for ikke å ha kontrollert finansieringen. Dette taler derfor mot en kontroll- og informasjonsplikt for megler.

Alt i alt finnes gode argumenter både for og imot en plikt for megler til å undersøke og informere om kjøpers finansiering fordi det finnes mange finansieringsmetoder, oppdragstyper og partstyper. Dette mangfoldet kan gjøre at en generell regel i den ene eller andre retningen ikke passer i alle tilfeller. En regel som kan tilpasses hvert enkelt tilfelle vil antakelig være det beste når situasjonene er så ulikartede. Av den grunn kan en generell regel om at megler har, eller ikke har, plikt til å kontrollere og informere kjøpers finansiering bli for absolutt. På den annen side gir en generell regel mer forutberegnelighet for alle involverte parter inkludert meglerbransjen. En generell regel er dessuten å foretrekke for å ha en klar hovedregel som utgangspunkt for rettstilstanden. Reelle hensyn taler, etter min mening, for en generell regel med plikt for megler, men som har fleksible elementer som gjør at hver situasjons særegenhet blir ivaretatt.

\subsection{Juridisk litteratur}

Selv om det finnes mye juridisk litteratur om eiendomsmegling, er spørsmålet om eiendomsmeglers plikt til å undersøke og informere om kjøpers finansiering lite behandlet $\mathrm{i}$ 
litteraturen. Så vidt vites er det kun Rosén og Torsteinsen og Bråthen og Solli som har behandlet problemstillingen direkte.

\subsubsection{Bråthen og Solli}

I sin lærebok om praktisk eiendomsmegling kommer Bråthen og Solli så vidt inn på spørsmålet om finansieringskontroll ${ }^{33}$. De skriver at i forbindelse med formidling av bud til selgeren vil megleren uoppfordret gi sin vurdering av det enkelte bud overfor selgeren. I følge forfatterne er det ikke uvanlig at megler som grunnlag for denne vurderingen forsøker å undersøke budgivers finansiering. Etter dette tar forfatterne samme utgangspunkt som Høyesterett gjorde i 1993, og de går dermed ikke lenger enn hva som kan utledes av hittil gjennomgåtte rettskilder.

\subsubsection{Rosén og Torsteinsen}

Rosén og Torsteinsen har gitt ut to utgaver av "Eiendomsmegling - rettslige spørsmål". I den siste utgaven fra 2008 mener forfatterne at hovedregelen nå er motsatt av Høyesteretts utgangspunkt i 1993. De konkluderer med at eiendomsmeglere har en alminnelig plikt til å kontrollere kjøpers finansiering, "... med mindre det er betryggende grunnlag for å slutte at finansieringen er i orden"34. Dette finner de holdepunkter for i forarbeidene til 2007-loven, bransjepraksis og praksis fra Reklamasjonsnemnda. Forfatterne tar utgangspunkt i Høyesterettsdommen fra 1993, men legger særlig vekt på forarbeidene hvor de mener lovutvalget kommer med klare uttalelser om bransjepraksis som departementet og bransjeorganisasjonene ikke hadde innvendinger mot. I tillegg merker forfatterne seg særlig uttalelser om bransjepraksis fra Reklamasjonsnemnda hvor det uttales at meglere vanligvis undersøker finansieringen.

\footnotetext{
${ }^{33}$ Bråthen og Solli (2008), del 1, s. 141.

${ }^{34}$ Rosén og Torsteinsen (2008) s. 352 og 548.
} 
Forfatterne går et steg lengre enn forarbeidene når de, i motsetning til min forståelse av forarbeidene, mener at lovutvalgets uttalelser er klare og at det derfor er grunnlag for å snu utgangspunktet i gjeldende rett slik at megler nå har en alminnelig kontrollplikt. Etter min vurdering legger ikke forarbeidene til grunn en alminnelig plikt for megler, men viser derimot ved sine uttalelser at utviklingen går i en slik retning. Lovutvalgets uttalelser er etter min oppfatning ikke klare nok til at det er grunnlag for å konkludere med det motsatte utgangspunktet av det som hittil har vært gjeldende rett. Selv om forfatterne snur utgangspunktet, er de forholdsvis tilbakeholdne i beskrivelsen av kontrollens omfang, ettersom de skriver at eiendomsmeglere "i en viss utstrekning" må undersøke finansieringen.

\subsection{Bransjepraksis}

Etter å ha vært i kontakt med NEF (Norges Eiendomsmeglingsforbund), EFF (Eiendomsmeglingsforetakenes forening), Kredittilsynet, de største meglerforetakene og ansvarlig lærer for eiendomsmeglingsstudiet på BI for å kartlegge bransjepraksis kan følgende oppsummeres som gjeldende bransjepraksis. Kredittilsynet, som ikke har gjort noen omfattende vurdering av spørsmålet, har uttalt at megler i utgangspunktet bare plikter å kontrollere at det foreligger en finansieringsplan men at det ikke foreligger noen alminnelig plikt til å kontrollere selve finansieringen. Ansvarlig lærer for eiendomsmeglingsstudiet på BI informerte om at man bruker Høyesterettsdommen og praksis fra lagmannsrettene som utgangspunkt for gjeldende rett $\mathrm{i}$ undervisningen. NEF og EFF sitter ikke på informasjon om bransjepraksis, men meglerforetakene selv opplyser at de har interne rutiner for finansieringskontroll. De sjekker finansieringen så langt det er praktisk mulig og selger får informasjon om eventuell usikkerhet ved finansieringen eller dersom den er uavklart (sistnevnte kan ofte være tilfelle i budrunder på grunn av den nye 24-timers regelen, ettersom bankene ofte er stengt når det er aktuelt å kontrollere finansieringen). Utover dette opplyses det at det ikke er vanlig at megler forplikter seg ytterligere overfor selger til å undersøke finansieringen. Dette viser at bransjepraksis er i samsvar med forarbeidene til den nye eiendomsmeglingsloven. 


\subsection{Oppsummering av gjeldende rett - har megler plikt til å kontrollere og informere om kjøpers finansiering?}

Eiendomsmeglingsloven av 1938 startet med et krav til "god forretningsskikk", som i 1989-loven ble endret til "god meglerskikk". Dette utviklet seg til å bli en innarbeidet rettslig standard. Høyesterett slo i 1993 fast at utgangspunktet i standarden om god meglerskikk er at eiendomsmegler ikke har noen alminnelig plikt til å undersøke kjøpers finansiering hvis ikke særlige omstendigheter tilsier det. Dette ble fulgt opp og presisert i etterfølgende praksis fra lagmannsrettene og Reklamasjonsnemnda for eiendomsmeglingstjenester. I følge lagmannsrettspraksis har ikke megler noen informasjonsplikt der selger allerede sitter på den aktuelle informasjonen. Meglers kontrollog informasjonsplikt vil avhenge av hva som er praktisk mulig å fremskaffe om kjøpers finansielle stilling.

Hvorvidt megler kan informere selger om eventuell usikkerhet ved finansieringen i stedet for å kontrollere denne er imidlertid noe usikkert etter gjeldende rett. Ifølge Høyesterettsdommen fra 1993 er det usikkert om ” ... megleren i alle tilfeller kan nøye seg med å gjøre sin tvil kjent for kjøperen [dette er skrivefeil og må være selgeren]”. LB 1996 s. 317 legger til grunn at megler i det minste må ”... gjøre selgeren kjent med de omstendigheter som skaper tvilen”. Reklamasjonsnemnda uttaler at megler enten må ”...iverksette nærmere undersøkelser eller i hvert fall gjøre selger kjent med den tvilen som foreligger, jf. Rt. 1993 s. 156" ${ }^{35}$. I Krystallen saken fastslår tingretten at megler alternativt måtte "...ha informert selger om den usikkerhet som eventuelt forelå, slik at selger selv kunne ha tatt stilling til prosjektrisikoen". De andre rettskildene, herunder forarbeidene til den nye loven, tar ikke stilling til om megler kan informere selger som alternativ til kontroll. Disse sier kun at megler må informere selger når kjøpers finansiering er usikker. Etter min vurdering ser riktignok forarbeidene ut til å legge til grunn at manglende kontroll i seg selv er et tegn på usikker finansiering som megler må informere om $^{36}$. Etter Krystallen saken kan det kanskje derfor legges til grunn at informasjon kan være et alternativ til kontroll. Saken er imidlertid ikke rettskraftig avgjort og forholdet er vurdert ut fra en avtalebestemmelse og ikke standarden om god meglerskikk. I tillegg er dette den eneste dommen etter forarbeidene til den nye loven som er tause om spørsmålet. Det er derfor mange usikkerhetsmomenter. Om megler kan nøye seg med å informere selger om usikkerhet ved kjøpers finansiering, i stedet for å kontrollere, må antakelig av den grunn bedømmes konkret i hvert enkelt tilfelle.

\footnotetext{
${ }^{35}$ Reklamasjonsnemnda 2005/124.

${ }^{36}$ Se punkt 2.2 .
} 
Den nye eiendomsmeglingsloven trådte i kraft 1. januar 2008, og forarbeidene til denne oppsummerer og presiserer rettstilstanden i forhold til hva som ligger i kravet til god meglerskikk. Det er tydelig at disse forarbeidene går lenger enn utgangspunktet som ble lagt til grunn av Høyesterett i 1993. Høyesterett legger til grunn at megler kun må iverksette nærmere undersøkelser når det er grunn til å tvile på kjøperens betalingsevne, og at megler må informere selger om dette. Forarbeidene slår derimot fast at finansieringen skal undersøkes så langt det er mulig, og informeres om når den fremstår som usikker. Lovutvalget utnytter derfor den dynamiske karakteren i standarden om god meglerskikk ved å gå et skritt videre fra Høyesterett. Selv om utviklingen ikke kommer direkte til syne i lovteksten bidrar forarbeidene til en rettsutvikling ved å åpne for at rettstilstanden kan bevege seg mot en utvidet, om ikke generell, plikt for megler til å gjennomføre finansieringskontroll av kjøpere. Rosén og Torsteinsens oppfatning går enda lenger enn forarbeidene. Forfatterne hevder at utgangspunktet fra Høyesterettsdommen i 1993 må være "motsatt" - at megler nå har en alminnelig plikt til å kontrollere kjøpers finansiering ${ }^{37}$, riktignok $i$ en viss utstrekning ${ }^{38}$.

Krystallen saken fra januar 2009 pålegger megler ansvar fordi kjøpers finansiering ikke ble kontrollert. Dette var den første dommen etter den nye loven og den siste i rekken av rettspraksis om finanskontroll. Ansvaret ble riktignok pålagt på grunnlag av en avtalebestemmelse og ikke på grunnlag av forsømmelse av standarden om god meglerskikk, men prinsippene i dommen kan etter min mening ha overføringsverdi til standarden om god meglerskikk ${ }^{39}$. Megler ble ansett å ha en plikt til å kontrollere at kjøper har en realistisk betalingsplan og eventuelt kontrollere kjøpers økonomiske soliditet. I tillegg mente retten at megler har plikt til å informere selger om eventuell tvil ved finansieringen. Retten vurderte det slik at omfanget av plikten beror på risikomomentene $\mathrm{i}$ den enkelte transaksjon. Dommen er ikke rettskraftig og ankesaken skal opp i Borgarting Lagmannsrett i desember 2009.

\footnotetext{
${ }^{37}$ Rosén og Torsteinsen (2008) s. 548.

${ }^{38}$ Rosén og Torsteinsen (2008) s. 352.

${ }^{39}$ Se punkt 2.5.1.
} 
Bransjepraksis viser dessuten at finansieringen vanligvis kontrolleres og at bransjen har interne rutiner på hvordan undersøkelsene skal gjennomføres. Det er mange gode argumenter for og i mot en plikt for eiendomsmeglere til å sjekke kjøpers finansielle stilling. Reelle hensyn, blant annet hensynet til de involverte parters forutberegnelighet, tilsier at man opererer med en hovedregel om at megleren har en generell plikt å kontrollere kjøpers finansiering, men at regelen har en viss fleksibilitet som gjør at man kan ta hensyn til hver enkelt situasjon.

Gjennomgangen av relevante rettskilder viser at rettstilstanden ikke er klar når det gjelder eiendomsmeglers plikt til å undersøke kjøpers finansiering. Likevel kan man etter mitt syn konkludere med at eiendomsmegler etter gjeldende rett $\mathrm{i}$ en viss grad har en plikt til å kontrollere kjøpers finansiering hvor særlige omstendigheter tilsier det. Megler har dessuten en informasjonsplikt der finansieringen fremstår som usikker.

Det gjenstår imidlertid å kartlegge hvilke særlige omstendigheter som tilsier at megler har en plikt til å kontrollere og informere om finansieringen i det enkelte tilfellet.

\section{Særlige omstendigheter}

\subsection{Innledning}

I punkt $2.11 \mathrm{kom}$ jeg til at megler har en viss plikt til å undersøke kjøpers finansiering dersom særlige omstendigheter tilsier det, og at megler har en informasjonsplikt der finansieringen fremstår som usikker. Ettersom det må foreligge særlige omstendigheter for at det skal være en kontrollplikt er det ingen generell undersøkelses- eller informasjonsplikt. Det må derfor vurderes konkret i hvert enkelt tilfelle om det foreligger særlige omstendigheter som taler for at megler har en undersøkelses- og kontrollplikt. De særlige omstendighetene vil utgjøre momenter, som ikke alene er avgjørende, men vil 
inngå i en helhetsvurdering. Noen momenter kan veie tyngre enn andre og det kan variere hvor ofte de ulike momentene foreligger. Flere momenter kan også foreligge samtidig.

De særlige omstendighetene kan innebære en økt risiko for at selger ikke får oppgjør. I så tilfelle tilsier det at megler i større grad plikter å kontrollere kjøpers finansiering. Foreligger det omstendigheter som derimot reduserer risikoen kan de være argumenter mot en kontroll- og informasjonsplikt i det konkrete tilfellet.

Formålet med denne delen av oppgaven er å identifisere omstendigheter som utgjør momenter som taler for en kontrollplikt. Følgende omstendigheter skal vurderes:

- Typen meglingsoppdrag

- Finansieringsmåte

- Partene og deres profesjonalitet

- Megler har fullmakt til å akseptere bud på vegne av selger

- Forskuddsinnbetaling - mislighold

- Budskjema med finansieringsplan benyttes

- Eiendomsmeglers markedsføring

\subsection{Typen meglingsoppdrag}

\subsubsection{Kort om ulike typer oppdrag og deres kjennetegn}

Det har ingen betydning at forskjellige lover (avhendingsloven og bustadoppføringsloven) regulerer de ulike formene for eiendomsoverdragelse. I forhold til meglers finansieringskontroll, og meglingsoppdraget før øvrig, gjelder kravet om god meglerskikk i eiendomsmeglingsloven i alle tilfeller.

Normalsituasjonen er som tidligere nevnt oppdrag vedrørende salg av brukte eller ferdigstilte boliger hvor kjøper og selger er privatpersoner og/eller næringsdrivende. Normalsalg er i seg selv ikke er en særlig omstendighet som tilsier at megler har plikt til å undersøke og informere om kjøpers finansiering. Det er særlige omstendigheter innenfor 
denne oppdragstypen som er interessant for vurderingen og som eventuelt tilsier en plikt til finansieringskontroll.

Prosjektsalg er salg av boliger som ikke er ferdigstilt, som enten er under bygging eller under planlegging ${ }^{40}$. Kjøper er enten en privatperson eller en næringsdrivende, mens selger oftest er en profesjonell næringsdrivende. En privatperson kan også være selger, eksempelvis hvor man bygger en tomannsbolig og selger den ene for å bidra til finansieringen av sin del av tomannsboligen.

Den forskjellen mellom oppdragstypene som er relevant i relasjon til kontroll av finansieringen knytter seg til hvordan oppgjøret foretas. Både ved normaloppdrag og prosjektoppdrag er det ganske vanlig at det ytes et forskudd på $10 \%$ ved kontraktsinngåelsen, og at resten av kjøpesummen betales ved overtakelse. Forskjellen består imidlertid i at tidsperioden mellom kontraktsinngåelsen og overtakelsen er lengre ved prosjektsalg ettersom eiendommen(e) ikke er ferdigstilt.

\subsubsection{Prosjektoppdrag}

Den lange tidsperioden mellom kontraktsinngåelse og overtakelse, som kan kalles tidsmomentet og som særpreger prosjektoppdrag, byr på problemer for megler når han skal kontrollere kjøpers finansielle stilling. Dersom megler kontrollerer kjøpers finansiering ved kontraktsinngåelsen er ikke det noen garanti for at kjøper faktisk er betalingsdyktig ved den senere overtakelsen. Dette presiseres også i forarbeidene ${ }^{41}$. Kjøpers finansielle stilling kan på ulike måter, og av forskjellige årsaker, endres vesentlig fra kontraktsinngåelsen til overtakelsen. For eksempel kan kjøperen komme i økonomiske vanskeligheter, og i verste fall gå konkurs. Slike forandringer er umulig for megler å oppdage gjennom en kontroll på tidspunktet for aksept av bud eller på kontraktstidspunktet. Megler kan derfor ikke ha risikoen for at kjøper ikke kan gjøre opp for seg ved overtakelsen dersom han har foretatt

\footnotetext{
${ }^{40}$ Bråten og Solli (2008), del 2, s. 83.

${ }^{41}$ NOU 2006:1 s. 126.
} 
en forsvarlig kontroll på et eller begge av disse tidspunktene ${ }^{42}$. Tidsmomentet ved prosjektsalg tilsier derfor at meglers plikt er begrenset til å kontrollere kjøpers finansiering ved aksept av bud og/eller ved kontraktsinngåelsen. Dette er tilsvarende som ved normalsalg.

Informasjonsplikten er den samme ved prosjektsalg som ved normalsalg når finansieringen er ubekreftet eller på annen måte usikker. I begge typer av salg er dette noe megler må informere selger om. Dette gjelder også dersom han får faktisk kunnskap underveis, frem til overtakelsestidspunktet, som tyder på at kjøper ikke kan gjøre opp for seg. På den annen side må megler antas å ha en informasjonsplikt overfor selger om den særlige risikoen som knytter seg til tidsmomentet.

Etter dette er det klart at prosjektsalg i seg selv ikke utgjør noen særlig omstendighet som tilsier at megler har en større grad av kontrollplikt enn i normalsalgstilfellene. I utgangspunktet gjelder dette også for informasjonsplikten, men den særlige risikoen som følger av tidsmomentet i prosjektsalg bør selger informeres om (her kan imidlertid selgers profesjonalitet tilsi en annen løsning, se punkt 3.4.1 om dette).

Et annet problem ved prosjektsalg er at det kan oppstå tidsnød i selve salgsprosessen. Banken som skal finansiere prosjektet kan stille som vilkår at et gitt antall leiligheter er solgt før byggelånet utbetales. Utbygger er i så fall avhengig av at megler har solgt dette antallet før man kan starte byggeprosessen. Megler vil da ha et tidspress på seg dersom utbygger vil starte byggingen snarest. I ettertid vil kanskje megler argumentere med at han ikke hadde tid til å kontrollere kjøpernes finansiering i tilstrekkelig grad på grunn av tidsnød. Spørsmålet er om tidsnøden som kan oppstå i prosjektsalg kan være et moment som tilsier at meglers plikt til å kontrollere og informere om finansieringen reduseres i slike tilfeller. I følge Reklamasjonsnemnda ${ }^{43}$ og Krystallen saken er ikke kapasitetsproblemer

\footnotetext{
${ }^{42}$ Reklamasjonsnemnda 2005/124.

${ }^{43}$ Reklamasjonsnemnda 1994/63. Megleren ble i denne saken ansett å ha opptrådt i strid med god meglerskikk på annet grunnlag enn manglende finansieringskontroll.
} 
som følge av tidsnød en akseptabel unnskyldning for at et salgsoppdrag ikke blir fulgt ordentlig opp. Det påpekes at kapasitetsproblemer snarere er en skjerpende omstendighet når det klages over utilfredsstillende behandling og oppfølgning av oppdrag. Dette fordi det er viktig at ethvert eiendomsmeglerforetak påser at oppdragsmengden ikke overstiger kapasiteten til enhver tid. Tidsnøden vil dessuten bidra til at risikoen for at selger får oppgjør øker. Det er derfor ingen grunn til at meglers kontroll- og informasjonsplikt skal reduseres. Tidsnød ved utførelsen av oppdraget, som er grunnet oppdragsgivers ønsker, og som megler har godtatt, er derfor ikke et moment som taler mot plikt til finansieringskontroll.

Det er etter dette klart at verken prosjektsalg i seg selv eller det forhold at det kan oppstå tidsnød ved slike salg utgjør særlige omstendigheter som tilsier at megler har en større grad av kontroll- og informasjonsplikt enn i normalsalgstilfellene. Megler bør derimot informere om den særlige risikoen som følger av tidsmomentet i prosjektsalg.

\subsection{Finansieringsmåte}

Måten kjøper planlegger å finansiere et eiendomskjøp på kan ha betydning for meglers plikt til å kontrollere og informere finansieringen. Det er flere muligheter å finansiere et eiendomskjøp på, og ofte er finansieringen sammensatt av flere finansieringskilder som kan inkludere både egenkapital og fremmedkapital. Lån og egenkapital er mye brukt ${ }^{44}$. Videresalg av eksisterende bolig, som er også er en vanlig finansieringskilde, er samtidig en måte å frigjøre egenkapital på. I byggeprosjekter kan investorer basere finansieringen på å selge eiendommen videre før overtakelse. Ved kontraktsinngåelse betales vanligvis en prosentandel av den totale kjøpesummen som forskudd. Resten betales ved overtakelse etter ferdigstillelse. I løpet av denne perioden kan eiendommens verdi øke. Investorer som selger før overtakelse kan derfor tjene penger ved at de får igjen mer enn det forskuddet de betalte ved kontraktsinngåelsen.

\footnotetext{
${ }^{44}$ Bråten og Solli (2008), del 1, s. 203.
} 


\subsubsection{Lånefinansiering}

Lånefinansiering er en svært vanlig finansieringsform for alle typer eiendomskjøp.

Finansieringsmåten kan i seg selv være en særlig omstendighet som tilsier at megler har en større eller mindre grad av kontroll- og informasjonsplikt. Graden av meglers plikt er avhengig av hvor usikker lånefinansieringen fremstår i det enkelte tilfellet. Det avgjørende er derfor hva som er opplyst eller dokumentert av kjøper. Desto sikrere opplysninger eller dokumentasjon kjøper har for at lånefinansieringen er i orden, og desto større sikkerhet denne gir for at oppgjør vil skje, jo mindre plikt vil megler ha til å kontrollere ytterligere eller gi informasjon om eventuell usikkerhet. I denne sammenheng brukes blant annet uttrykk som finansieringsplan, lånetilsagn, finansieringsbevis og bankgaranti. Det er viktig at det skilles mellom disse da det er stor forskjell på finansieringens sikkerhet om kjøper i en finansieringsplan i budskjemaet opplyser at han skal finansiere kjøpet ved lån, eller om kjøper fremlegger en bankgaranti han har påtatt seg å stille.

Dersom kjøper opplyser megler om at han har lånefinansiering eller har fătt lånetilsagn, enten muntlig eller skriftlig i en finansieringsplan, må dette normalt sjekkes ytterligere av megler etter gjeldende rett ${ }^{45}$. Det er da tilstrekkelig at megler făr kjøpers opplysninger bekreftet muntlig av banken ${ }^{46}$. En slik bekreftelse reduserer risikoen for at opplysningene er feilaktige. Fremlegger kjøperen et finansieringsbevis har megler i tillegg en skriftlig bekreftelse fra finansieringsinstitusjonen på at kjøper har fått et lånetilsagn. Dette gir større grad av sikkerhet enn en muntlig bekreftelse. Megler plikter imidlertid ikke å sørge for at kjøper skaffer finansieringsbevis ${ }^{47}$. Er det fremlagt plikter han derfor ikke å foreta seg noe ytterligere. Tilsvarende gjelder desto mer for bankgarantier, som gir enda større sikkerhet da det er et bindende løfte fra kjøpers bank om å betale et avtalt beløp til selgeren, i henhold til de forutsetninger som er gitt i garantiteksten. Er det avtalt at kjøper skal stille

\footnotetext{
${ }^{45}$ Reklamasjonsnemnda 2001/75, 2002/44, 2003/75, 2004/82 og NOU 2006:1 s. 125.

${ }^{46}$ Reklamasjonsnemnda 2001/75, 2002/44, 2003/75 og 2004/82.

${ }^{47}$ Krystallen saken og Reklamasjonsnemnda 2006/343.
} 
bankgaranti kan det ikke kreves at megler undersøker kjøpers mulighet til å fremlegge dette ved vanlig boligkjøp ${ }^{48}$.

Grunnen til at megler ikke plikter å undersøke om kjøper har mulighet til å fremlegge bankgaranti kan være at bankgarantier brukes for å stille sikkerhet for egne forpliktelser i en kontrakt. Dette gjør at kjøper oftest ikke kan stille med noen bankgaranti før kjøpekontrakten faktisk er inngått. Opplysninger om finansiering og skriftlige finansieringsbevis gis derimot vanligvis i forbindelse med aksept av bud. Praktisk sett forekommer nok derfor bankgarantier oftest ved prosjektsalg og er antakelig mest vanlig mellom næringsdrivende parter.

Et noe annet spørsmål er hvorvidt megler har plikt til å følge opp kjøper der partene har avtalt at kjøper skal fremlegge bankgaranti, eller der kjøper har tilbudt seg dette. Det kan etter rettspraksis normalt ikke kreves at megleren sørger for at kjøper fremskaffer bankgaranti i disse tilfellene ${ }^{49}$.

Det kan også være tilfelle at det ikke foreligger noen opplysninger om kjøpers finansiering. Denne situasjonen medfører størst risiko for at selger ikke får oppgjør, og tilsier derfor at megler plikter å kontrollere og informere selger.

Opplysningene eller dokumentasjonen kjøper gir megler avgjør graden av meglers kontrollog informasjonsplikt. Fremlegger kjøper bankgaranti, skriftlig finansieringsbevis eller făr megler bekreftet kjøpers opplysninger om lånefinansiering muntlig, er meglers kontrollplikt oppfylt. Dette fordi alle de nevnte dokumentasjonsmåtene reduserer selgers risiko for ikke å få oppgjør. Dersom det ikke foreligger noen opplysninger fra kjøper om finansieringen vil derimot lånefinansieringen i seg selv være en særlig omstendighet som tilsier kontroll- og informasjonsplikt.

\subsubsection{Egenkapital}

Egenkapital kan være kontanter kjøper allerede har, for eksempel bankinnskudd, eller kontanter som frigis ved salg av eiendeler ${ }^{50}$. Her omtales kun finansiering ved egenkapital

\footnotetext{
${ }^{48}$ RG 2004 s. 552.

49 Ibid.

${ }^{50}$ Bråten og Solli (2008), del 1, s. 203.
} 
som allerede er frigitt. For egenkapital som ennå ikke er frigitt vises det til punkt 3.3.3 om videresalg av eksisterende bolig.

Det avgjørende for meglers kontrollplikt av egenkapital er i hva som er praktisk mulig å undersøke.

Står kontantene i banken kan dette kontrolleres dersom megler får tillatelse til det av kjøper. Kjøperen opphever med dette bankens taushetsplikt, og det følger da av forarbeidene ${ }^{51}$ og bransjepraksis at megler sjekker opplysninger om innestående beløp på bankkontoen ved å få en muntlig bekreftelse fra banken på tilsvarende måte som ved kontroll av lånetilsagn.

Opplyser kjøper at pengene oppbevares hjemme, for eksempel i madrassen eller i en safe, blir den praktiske muligheten for å få en bekreftelse på at kjøperen har pengene en annen. Reklamasjonsnemnda har uttalt at det normalt ikke kan kreves at megler kontrollerer kjøpers egenkapital der dette oppgis å være finansieringskilden ${ }^{52}$.

Er det praktisk vanskelig å kontrollere om kjøperen har den opplyste egenkapitalen tilsier reelle hensyn at megler heller ikke har noen undersøkelsesplikt $t^{53}$, til tross for at en kontroll ville ha redusert selgers risiko for å få oppgjør. Tilsvarende følger av forarbeidene hvor det fremgår at "budgivers finansiering kontrolleres så langt det er mulig" "54 . Også bransjepraksis legger dette til grunn ${ }^{55}$. Det samme gjelder for informasjonsplikten da rettspraksis fastslår at denne avhenger av hva som er praktisk mulig å fremskaffe ${ }^{56}$. Hvis megler ikke undersøker, fordi han ikke kan sies å ha plikt til det, må det likevel antas at han

\footnotetext{
${ }^{51}$ NOU 2006:1 s. 125.

${ }^{52}$ Reklamasjonsnemnda 2004/82.

${ }^{53}$ Se punkt 2.8 .

${ }^{54}$ NOU 2006:1 s. 126.

${ }^{55}$ Se punkt 2.10.

${ }^{56}$ RG 2004 s.552.
} 
må informere selger om usikkerheten manglende kontroll medfører for om kjøper faktisk har det påståtte kontantbeløp. Er det derimot praktisk mulig og tilrettelagt for at megler kan kontrollere kjøpers egenkapital, for eksempel ved at bankens taushetsplikt er opphevet, tilsier det at megler har plikt til å kontrollere. Dette fordi en kontroll øker sjansen for at selger er sikret den betalingen han har krav på.

\subsubsection{Videresalg av eksisterende bolig}

Når man videreselger eksisterende bolig, for å finansiere et eiendomskjøp, frigir man kapital. I prinsippet består derfor finansieringen av egenkapital. Noen ganger kjøper man kanskje en ny bolig før man har solgt og fått oppgjør for den gamle boligen. Da vil ikke kapitalen være frigitt på kjøpstidspunktet, og man må ty til mellomfinansiering, et midlertidig og kortsiktig lån ${ }^{57}$, for å unngå å misligholde kjøpesummen. Der kjøperen ikke har ordnet mellomfinansiering men satser på at oppgjørstidspunktet for den gamle boligen faller før i tid enn oppgjøret for den nye kan det derfor oppstå problemer. Det er denne situasjonen som skal omtales i det følgende.

Hvorvidt videresalg av eksisterende bolig som finansieringskilde er et moment for at megler har en kontroll- og informasjonsplikt vil bero på hvor langt salgsprosessen av kjøpers eksisterende bolig har kommet. Det vil derfor være av stor betydning at megler avklarer dette med kjøper for å kunne vurdere risikoen av finansieringsmåten. Megler kan allerede sies å ha en kontroll- og informasjonsplikt ved at denne avklaringen bør foretas dersom kjøper ikke har mellomfinansiering.

Er boligen solgt, vil det ha betydning når oppgjør skal skje. Skulle oppgjøret ha skjedd, slik at kjøpers kjøper er i mislighold, er kjøpers betalingsevne avhengig av sin egen kjøpers finansielle stilling. Megler kan ikke kontrollere sistnevntes betalingsevne og finansieringen blir i så tilfelle meget usikker. Skal derimot oppgjør skje innen kort tid vil finansieringen fremstå som relativt sikker, forutsatt at det ikke foreligger omstendigheter som svekker

\footnotetext{
${ }^{57}$ Bråten og Solli (2008), del 1, s. 204.
} 
troverdigheten for at dette oppgjøret skal gå problemfritt. Megler bør i slike tilfeller få bekreftet at oppgjøret faktisk er gjennomført av kjøpers kjøper. Dersom oppgjør derimot skal skje langt frem i tid, er kjøper ikke i stand til å betale hvis ikke overtakelsen, og eventuelt avtaleinngåelsen, for kjøpers nye boligen er etter oppgjøret for kjøpers eksisterende bolig. I så fall må megler informere selger om dette.

Har kjøper ikke solgt boligen, vil det representere den situasjonen hvor videresalg av eksisterende bolig har størst risiko. Dette fordi man ikke har grunnlag for å vite hvor lett salget av eiendommen vil gå, og om den i det hele tatt vil bli solgt. Selv om man får opplysninger som gjør at man kan være i stand til å vurdere dette, vil man aldri være sikker på at det er slik det faktisk vil foregå. Megler må derfor informere selgeren om den risikoen som foreligger når den boligen kjøper baserer finansieringen på ikke er solgt.

At kjøper skal benytte seg av salg av eksisterende bolig som ledd i sin finansiering er etter dette en særlig omstendighet som tilsier at finansieringen, og dermed selgers mulighet for å få oppgjør, kan være så usikker at megler har en kontroll- og informasjonsplikt. Det vil være viktig å finne ut om kjøper har mellomfinansiering. Har ikke kjøper det må megler undersøke om eiendommen er solgt eller ikke, og når oppgjør eventuelt kan forventes. Resultatet av undersøkelsene må megler informere om og bruke som grunnlag i sin rådgivning overfor selger.

\subsubsection{Videresalg før overtakelse i byggeprosjekter}

Når en person eller et selskap kjøper en uferdig boligeiendom i et byggeprosjekt, og baserer finansieringen på videresalg av denne før overtakelsen, må vedkommende faktisk få solgt før overtakelsen for å kunne oppfylle sin betalingsforpliktelse overfor selger. Kjøperen er også avhengig av at den nye kjøperen gjør opp for seg. Når overtakelsen normalt er langt frem i tid kan markedsutviklingen ha hatt en negativ utvikling. Da vil den opprinnelige kjøperen sitte igjen med et skyldig restbeløp overfor utbyggeren/selgeren som utgjør et tap for denne. Er det situasjonen, og finansieringen kun er basert på videresalg før overtakelse, risikerer selger at kjøper ikke har evne til å oppfylle sin betalingsforpliktelse. Selv om 
betalingsevnen eventuelt er til stede, kan man også risikere at kjøperen velger å ikke gjøre opp for seg.

$\AA$ finansiere et boligkjøp ved videresalg før overtakelse kan anses som relativt sikkert dersom slike boligprosjekter statistisk sett øker i verdi. Dette vil særlig gjelde dersom risikoen ved det konkrete prosjektet anses å være liten. På den annen side kan man aldri vite hvordan eiendomsmarkedet utvikler seg, uansett statistikk. Etter min mening burde en slik måte å finansiere kjøp på derfor anses som usikker, og finansieringsmåten medfører øt risiko for at selger ikke får oppgjør. Dette tilsier at megler har en plikt til å kontrollere finansieringen ytterligere og informere kjøper om usikkerheten.

Spørsmålet er så hva megler faktisk kan gjøre for å kontrollere finansieringen ytterligere når den kun er basert på videresalg av kjøpeobjektet. Kjøper må nødvendigvis ha forskuddet på plass. Dette kan megler undersøke, og hans undersøkelsesplikt avhenger igjen av måten forskuddet er finansiert på (se ovenfor, særlig om lånefinansiering og egenkapital). Selve finansieringsmåten, videresalg før overtakelse, tilsier at kjøperen ikke har betalingsevne for resten av kjøpesummen når budet inngis eller kontrakten inngås. Dermed er det en stor risiko for at selger ikke får oppgjør og dette taler for at megler i det minste må informere selger om den usikkerheten det representerer.

Meglers eneste mulighet til kontroll er å sjekke at kjøperen har betalingsevne når budet inngis og/eller på avtaletidspunktet. Betalingsevnen kan imidlertid forandre seg drastisk frem til overtakelsestidspunktet, da det er lang tid til overtakelsen, og en kontroll kan derfor virke uhensiktsmessig. I Krystallen saken la retten derimot til grunn at det har verdi å sjekke at kjøperen kan betale for seg på avtaletidspunktet, fordi overtakelse langt frem i tid medfører en større risiko for selgers oppgjør enn ellers. At kjøper har betalingsevne på avtaletidspunktet er et moment som taler for at han har det på overtakelsestidspunktet. Det er også mulig at en betalingsvillig kjøper som ikke har betalingsevne klarer å skaffe kapital til overtakelsen. Sannsynligheten for dette er imidlertid ikke like stor når man ikke er 
betalingsdyktig på avtaletidspunktet, og vil således innebære en større risiko som megler i tilfelle må informere selger om.

Finansiering som er basert på videresalg må antas å være risikofull når det gjelder sannsynligheten for at oppgjør ytes. Finansieringsmåten er derfor en særlig omstendighet som tilsier at megler har plikt til å kontrollere kjøpers finansiering senest på avtaletidspunktet. I tillegg taler det for at megler informerer selger om usikkerheten ved at kjøperen skal finansiere kjøpet ved videresalg før overtakelse, uansett om kjøperen har betalingsevne på avtaletidspunktet eller ikke.

\subsection{Partene og deres profesjonalitet}

\subsubsection{Selger}

Hvorvidt selger er profesjonell i eiendomsmarkedet eller ikke, kan påvirke meglers plikt til å undersøke og informere om kjøpers finansiering.

Dersom selger for eksempel er utbygger i et eiendomsprosjekt, en privat investor eller et selskap som driver med eiendom, må det antas at selger har innsikt i eiendomsmarkedet og eiendomsbransjen. Har selger kunnskap om kjøpers finansiering vil han kunne vurdere finansieringen på egenhånd uten ytterligere informasjon og rådgivning fra megleren.

Er selger derimot en vanlig privatperson, uten særskilt kunnskap om eiendomsmarkedet og eiendomsbransjen, tilsier det at megler i større grad har en kontroll- og informasjonsplikt fordi selger ikke har tilstrekkelig evne til å vurdere eventuelle risikomomenter når det gjelder kjøpers finansiering.

Der selger sitter på samme informasjon som megler om kjøpers finansiering, og er i stand til å vurdere risikoen ved å akseptere et bud med en slik finansiering (uansett profesjonalitet), taler det for at megler ikke har plikt til å undersøke finansieringen ytterligere eller informere om forholdene. Aksepterer selger (uansett profesjonalitet) budet $\mathrm{i}$ 
en slik situasjon kan han sies å ha akseptert risikoen dette medfører. Dette følger også av rettspraksis ${ }^{58}$. Forutsetningen er imidlertid at selger er i stand til å vurdere informasjonen. Er det klart at han ikke i stand til det, må megler etter min mening informere om og gi sin vurdering av risikoen til selger.

Dette viser at om selger er profesjonell er det en omstendighet som tilsier at megler har en mindre grad av informasjonsplikt enn ellers. Dessuten vil det at selger sitter på samme informasjon om kjøpers finansiering som megler, og eventuelt er i stand til å vurdere risikoen for oppgjør selv, også være en omstendighet som tilsier en mindre grad av informasjonsplikt for megler.

\subsubsection{Kjøper}

Kjøpers profesjonalitet kan ved første øyekast vanskelig tenkes å påvirke meglerens plikt til å kontrollere eller informere om kjøpers finansiering, ettersom formålet med å gjøre dette er å tilfredsstille selgers interesser. På den annen side kan det tenkes at det er forhold ved kjøper som nettopp gjør at dennes finansiering kan fremstå som usikker, og som er et moment som taler for en større plikt for megler til å kontrollere og informere.

Dersom kjøper er en profesjonell part, i form av å være en privat investor eller et investeringsselskap ${ }^{59}$, vil megler kunne få en plikt til å informere om finansieringen dersom selger/utbygger ikke ønsker finansiering i sitt byggeprosjekt som er basert på videresalg. At en kjøpekontrakt endres til å lyde på et selskap tilsier også at megler burde foreta nærmere undersøkelser av selskapet og dets betalingsevne og informere om dette ${ }^{60}$. I Krystallen saken la retten til grunn at når kjøper er nyetablerte selskaper og selskaper under stiftelse med lav egenkapital, skjerpes kravene til meglers undersøkelses- og opplysningsplikt da det representerer en økt tapsrisiko for selger.

\footnotetext{
${ }^{58}$ LB 1996 s. 317 og RG 2004 s. 552.

${ }^{59}$ Det presiseres at oppgaven kun omfatter kjøp av boligeiendom, og ikke næringseiendom.

${ }^{60}$ ADA-2006-D103.
} 
Av mindretallet i RG 2004 s. 552 ble det vektlagt at ettersom kjøperen ikke hadde noe bosted, inntekt, formue eller bankforbindelse i Norge tilsa det at megleren hadde en klar oppfordring til å foreta undersøkelser av kjøpers finansiering. Disiplinærnemnda for advokater har også lagt til grunn at en advokat, som her var megler, skulle ha informert selger om de problemer som kunne oppstå ved at kjøper i sin helhet skulle finansiere kjøpet med midler skaffet fra utlandet ${ }^{61}$.

Etter dette er det klart at det er flere omstendigheter ved kjøpers rolle som utgjør særlige omstendigheter som taler for en skjerpet plikt for megler til å kontrollere og informere om kjøpers finansiering.

\subsection{Megler har fullmakt til å akseptere bud på vegne av selger}

Som utgangspunkt har ikke megler noen fullmakt til å binde sin oppdragsgiver, jf. eml.§ 66. Likevel kan megler i enkelte tilfelle få fullmakt fra selger til å akseptere bud fra kjøpere. I så fall kan man si at det fordrer en større grad av aktsomhet fra megler, fordi han har fătt tillit fra selger ved en fullmakt for å sikre hans interesser på best mulig måte. Når selgers interesse først og fremst er å få oppgjør, vil en finansieringskontroll være essensiell. Slik sett kan man si at megler har en plikt til å avvise bud som ikke har tilfredsstillende finansiering. I så fall må megleren kontrollere finansieringen til budgiver. Det kan dessuten tenkes at to kjøpere fremsetter bud på samme tidspunkt. Megler er i slike tilfeller antakelig forpliktet til å akseptere det budet som har den sikreste finansieringen, og for å avgjøre dette må en kontroll foretas.

Et eksempel på at megler har fått en fullmakt kan være ved prosjektsalg hvor det brukes prisliste med faste priser. I slike tilfelle gjelder ofte først-til-mølla prinsippet. Da er det vanligvis en viss automatikk $i$ at den eller de kjøperne som først fremsetter et bindende tilbud får aksept. Siden det er forutbestemt hvilke bud som skal aksepteres gir derfor ikke

\footnotetext{
${ }^{61}$ ADA-2006-D103.
} 
fullmakten megler noen reell utvidet myndighet. Ved fastpris er derfor ikke fullmakten noen særlig omstendighet som påvirker meglers kontroll- og informasjonsplikt, fordi megler vil ha samme plikt til kontrollere og informere om finansieringen som $\mathrm{i}$ normaltilfellene. Har derimot megler fătt fullmakt når prisen ikke er fast, for eksempel dersom selger er svært utilgjengelig når salget skal skje grunnet utenlandsopphold, fordrer fullmakten en større aktsomhet fra megler enn i normaltilfellene. Megler må da i større grad forsikre seg om at budet som blir akseptert har en sikker finansiering siden han aksepterer på vegne av selgeren. Slike tilfeller er riktignok ikke særlig praktisk.

Dersom megler har fått fullmakt til å akseptere bud på vegne av selgeren, kan det tilsi at det fordrer en større aktsomhet fra megler i forhold til kontroll av finansieringen. Etter en kontroll vil megler ha et bedre grunnlag for å vurdere finansieringen og dermed akseptere det budet som har størst finansiell sikkerhet. Informasjonsplikten må antakelig på den annen side bli redusert da megler nettopp har fătt en myndighet til å akseptere bud uten å informere om de og drøfte de med selger.

\subsection{Forskuddsinnbetaling - mislighold}

Når det er avtalt at kjøper skal betale et forskudd, vil en finansieringskontroll ved avtaleinngåelsen ha avgjørende betydning for meglers rådgivning til selger om han bør fastholde avtalen eller ikke. Spesielt gjelder dette hvis et avtalt forskudd er misligholdt. Spørsmålet er om misligholdet kan tyde på at finansieringen i sin helhet ikke holder, slik at megler må kontrollere finansieringen og/eller informere selger om den usikkerheten misligholdet representerer.

Hensikten med forskuddet er å sikre at kjøpet blir gjennomført slik at selger får betaling. Med andre ord skal det være en sikkerhet for at kjøper har betalingsevne og er derfor i stor grad brukt i praksis. I følge Reklamasjonsnemnda ${ }^{62}$ er det også mye som taler for at megler sørger for at forskuddsbetaling avtales partene imellom, men omstendighetene kan variere

\footnotetext{
${ }^{62}$ Reklamasjonsnemnda 2005/19.
} 
slik at man ikke kan si at megler har en slik plikt. Forskuddet utgjør normalt $10 \%$ av kjøpesummen og betales vanligvis ved kontraktsinngåelsen.

I følge en avgjørelse fra Disiplinærnemnda for advokater ${ }^{63} \mathrm{kan}$ det at det skal betales mindre enn $10 \%$ forskudd i seg selv være et moment som taler for at megler har en plikt til å undersøke finansieringen. Særlig når forskuddet skal betales etter kontraktsinngåelsen er det viktig at megler informerer om hvilken risiko dette innebærer for selger.

På grunn av hensynet til selgers sikkerhet for oppgjør kan et mislighold med forskuddsinnbetalingen være en særlig omstendighet som tilsier at megler har en plikt til å kontrollere kjøpers finansiering ytterligere, og/eller informere kjøper om misligholdet og om aktuelle handlingsalternativ. Reklamasjonsnemnda har vært noe uklar i sin praksis hva gjelder forskuddsbetalingens betydning for meglers plikt til å kontrollere kjøpers finansiering. De har blant annet uttalt følgende: "Flertallet er for øvrig også tilbøyelig til å være enig med innklagede $i$ at forsinket innbetaling av kontantbeløp [som var forskuddet] sjelden er noe signal om alvorlige problemer med finansieringen av kjøpet" ${ }^{64}$. I en senere avgjørelse påpekte de derimot at manglende innbetaling av avtalt forskudd etter omstendighetene kan være et faresignal som kan tyde på finansieringsproblemer ${ }^{65}$. I en nylig avgjørelse ble megler pålagt ansvar for ikke å ha informert om mislighold med forskuddsinnbetalingen ${ }^{66}$. Dette er vage og motstridende formuleringer, men utviklingen viser at mislighold med forskuddsinnbetalingen kan tilsi at megler har en kontrollplikt, og i alle fall en informasjonsplikt. Lagmannsrettspraksis konstaterer også at mislighold av forskuddsinnbetaling kan være et tegn på finansieringsproblemer med hele kjøpesummen ${ }^{67}$. Etter min mening er derfor mislighold av forskuddsinnbetaling en særlig omstendighet som tilsier at megler må kontrollere og informere selger om. Dette kan kanskje betegnes som

\footnotetext{
${ }^{63}$ ADA-2006-D103.

${ }^{64}$ Reklamasjonsnemnda 1999/8.

${ }^{65}$ Reklamasjonsnemnda 2001/75.

${ }^{66}$ Reklamasjonsnemnda 2009/7.

${ }^{67}$ LB 1996 s. 317.
} 
antesipert mislighold av restkjøpesummen og dermed gi selger grunnlag til å heve kontrakten.

Det kan diskuteres om det burde brukes en høyere prosentsats enn $10 \%$ for forskuddsbetaling i prosjektsalg hvor det er en lengre tidsperiode mellom kontraktsinngåelsen og overtakelsen. En høyere risiko burde tilsi at man som selger også sikres i større grad ved avtaleinngåelsen.

\subsection{Budskjema med finansieringsplan benyttes}

I normalsituasjonen benyttes ofte et budskjema med en finansieringsplan, som kjøper kan fylle ut ved budgivningen. Selv om det vanligvis ikke er en tilsvarende budgivningsprosess ved prosjektsalg, kan det likevel være tilfelle at budskjema med finansieringsplan anvendes.

Når det foreligger et budskjema med en finansieringsplan i prospektet, som er en del av markedsføringen av boligen, kan det i seg selv kreve et minimum av aktsomhet fra megleren med tanke på finansieringskontroll. Forespørselen om finansieringsplaner kan tyde på at megleren ønsker å sjekke og informere om kjøpers finansiering. Det er også i meglers interesse at kjøpet gjennomføres uten finansieringsproblemer, da eventuelle problemer kan medføre ekstraarbeid og kanskje i verste fall et økonomisk ansvar for megler. Fylles budskjemaet ut med bankkontaktens detaljer oppheves dessuten bankens taushetsplikt og gjør kontrollen enklere.

At kjøper bes om å opplyse om finansieringsplanen, kan også sies å gi selger en forventning om at megler vil utføre et minimum av kontroll og underrette selger om finansieringen. Overfør kjøper kan det gi signaler om at megler har en slik intensjon og virke preventivt. Bransjepraksis viser dessuten at finansieringskontroll er vanlig i tilfeller hvor finansieringsplan benyttes. 
Benyttes et budskjema med finansieringsplan kan dette dermed være en særlig omstendighet som taler for at megler plikter å foreta en finansieringskontroll og informere selger om kjøpers finansiering.

\subsection{Eiendomsmeglers markedsføring}

Måten megler har markedsført seg på kan medføre at han plikter å gjøre mer omfattende undersøkelser av kjøpers finansiering, og underrette selger om finansieringen, enn det som følger av gjeldende rett. Dette er omtalt både i forarbeidene ${ }^{68}$ og i Nemndas praksis ${ }^{69}$.

Et problem man står overfor her er hvor tydelig og klar markedsføringen må være for at megler har påtatt seg å kontrollere og informere om kjøpers finansielle stilling. Dette sies det ikke noe om i forarbeidene. I Reklamasjonsnemndas avgjørelse 2000/100 hadde megler utad markedsført seg med at foretaket "har en egen evne til å sile ut potensielle kjøpere som er seriøse”. Dette var i følge Reklamasjonsnemnda ikke klart nok til at megler kunne pålegges noe strengere krav til finansieringskontroll enn det som gjaldt for bransjen generelt. Dette kan vise at markedsføringen må være ganske klar dersom den skal tolkes slik at megler har påtatt seg å kontrollere finansieringen og holde selger underrettet. Hvorvidt den spesifikt må nevne finansieringskontroll er usikkert.

Har megleren markedsført seg på en slik måte at han har påtatt seg å sjekke kjøpers finansiering er dette en særlig omstendighet som tilsier at han har plikt til å kontrollere og informere selger.

\subsection{Oppsummering særlige omstendigheter}

I punkt 2.11 var konklusjonen at det kan foreligge særlige omstendigheter som utgjør momenter i en konkret helhetsvurdering som taler for at megler har en kontroll- og

\footnotetext{
${ }^{68}$ NOU 2006:1 s. 125.

${ }^{69}$ Reklamasjonsnemnda 2000/100.
} 
informasjonsplikt. Gjennomgangen i dette kapittelet viser at det er flere slike særlige omstendigheter.

I prosjektsalg er tidsmomentet en særlig omstendighet som tilsier at megler har plikt til å informere selger om den risikoen dette medfører.

Lånefinansiering er i seg en særlig omstendighet som tilsier at megler har en kontroll- og informasjonsplikt når det ikke foreligger noen opplysninger og/eller dokumentasjon fra kjøper. Fremlegger derimot kjøper bankgaranti, skriftlig finansieringsbevis eller får megler bekreftet kjøpers opplysninger om lånefinansiering muntlig, er meglers kontrollplikt oppfylt. Dette fordi alle de nevnte dokumentasjonsmåtene reduserer selgers risiko for ikke å få oppgjør. Er kjøpers finansiering basert på egenkapital kan det tenkes at megler må informere om at dette er den finansieringsmåten som benyttes. Baserer kjøper sin finansiering på videresalg av eksisterende bolig er det en særlig omstendighet som taler for kontroll- og informasjonsplikt når den eksisterende boligen ikke er solgt eller dersom boligen er solgt men oppgjør ikke er mottatt. Finansiering ved videresalg av eiendom i byggeprosjekter før overtakelse er etter min mening meget risikofylt. Derfor er også denne finansieringsmåten i seg selv en særlig omstendighet som tilsier at megler har plikt til å kontrollere og informere om kjøpers finansiering.

Det er flere omstendigheter ved kjøpers rolle som utgjør særlige omstendigheter som taler for en skjerpet plikt for megler til å kontrollere og informere om kjøpers finansiering. Eksempler er når kjøper ikke har bolig, bankforbindelse eller formue i Norge, eller dersom kjøper er et nyetablert selskap eller et selskap under stiftelse med lav egenkapital.

Har megleren fullmakt fra selger til å akseptere bud, i tilfeller hvor fastpris ikke benyttes, er det en særlig omstendighet som taler for at megler ivaretar kjøpers interesser i større grad enn ellers, ved finansieringskontroll. 
Dersom en forskuddsinnbetaling blir misligholdt kan det være et faresignal om at kjøper har problemer med hele finansieringen. Misligholdet vil derfor være en særlig omstendighet som tilsier kontroll og informasjon. Skal det betales mindre enn $10 \%$ forskudd kan også det være en særlig omstendighet som taler for at megler har en plikt til å undersøke finansieringen. Særlig gjelder dette når forskuddet skal betales etter kontraktsinngåelse. Da må selger få informasjon om hvilken risiko dette representerer.

Benyttes budskjema med finansieringsplan kan det være en særlig omstendighet som tilsier at megler undersøker og informerer om finansieringen. Har megleren markedsført seg på en slik måte at han kan sies å ha påtatt seg å sjekke finansieringen, er også det en særlig omstendighet som taler for at han har en slik plikt.

Det finnes flere forhold som ikke utgjør særlige omstendigheter. Disse taler derfor mot at megler har kontroll- og informasjonsplikt.

Verken prosjektsalg i seg selv eller tidsnød ved slike salg utgjør særlige omstendigheter som tilsier at megler har en større grad av kontroll- og informasjonsplikt enn i normalsalgstilfellene.

Er finansieringen basert på egenkapital, vil megler normalt ikke ha plikt til å kontrollere finansieringen. Egenkapital som finansieringsmåte er derfor ingen særlig omstendighet.

Er selgeren en profesjonell part og sitter på samme informasjon om kjøpers finansiering som megler, kan han selv være i stand til å vurdere risikoen ved å akseptere bud fra budgiverne. I slike tilfeller utgjør ikke selgers rolle noen særlig omstendighet som tilsier at megler har plikt til å kontrollere og informere om kjøpers finansiering (hvis ikke det er klart at selger ikke er i stand til å vurdere dette på egenhånd).

Fullmakt til å akseptere bud kan være en særlig omstendighet som tilsier at megler ikke har informasjonsplikt overfor kjøperen når det gjelder kjøpers finansielle stilling. Dette fordi 
fullmakten nettopp er en myndighet gitt megler for å ta en avgjørelse uten å drøfte budene med selger.

Kort oppsummert vil de særlige omstendigheter øke risikoen for at selger ikke făr oppgjør. De særlige omstendighetene er da momenter i en helhetsvurdering som taler for en mer omfattende kontroll- og informasjonsplikt for megler. Omstendigheter som reduserer risikoen for at selger får oppgjør kan derimot være argumenter mot en kontroll- og informasjonsplikt i det konkrete tilfellet.

\section{Konsekvensene av pliktbrudd}

\subsection{Innledning}

I de foregående deler av oppgaven er det gjort rede for gjeldende rett når det gjelder eiendomsmeglers plikt til å kontrollere og informere om kjøpers finansiering (kapittel 2), og for hvilke særlige omstendigheter som kan tilsi at megler har slik plikt eller ikke (kapittel 3). Formålet med denne delen av oppgaven er å kartlegge hvilke konsekvenser som kan inntre når plikten forsømmes.

Det er flere mulige konsekvenser av pliktbrudd. Aktuelle konsekvenser når megler har forsømt en plikt til å kontrollere og/eller informere om kjøpers finansiering, og som skal vurderes her, er erstatning og nedsettelse av meglers vederlag. Offentligrettslige sanksjoner som tap av autorisasjon m.v. kan også inntre, men behandles ikke i det videre.

\subsection{Erstatning}

Både megleren som har forsømt seg og eiendomsmeglingsforetaket vedkommende megler jobber for kan stilles til ansvar for forsømmelsen ${ }^{70}$. Uansett ansvarssubjekt må vilkårene for å få tilkjent erstatning være oppfylt. Det må foreligge et ansvarsgrunnlag, et økonomisk

\footnotetext{
${ }^{70}$ Rosén og Torsteinsen (2008) s. 522.
} 
tap, årsakssammenheng mellom tapet og den skadevoldende handling (her: forsømmelsen av å kontrollere og/eller informere om finansieringen) og tapet må være adekvat eller påregnelig $^{71}$.

Eiendomsmegleres erstatningsansvar er ulovfestet ${ }^{72}$. Overfor oppdragsgiveren dreier det seg normalt om et erstatningsansvar i kontraktsforhold, da dette er et misligholdsansvar for kontraktsbrudd, mens et ansvar overfor oppdraggiverens medkontrahent (kjøper) er et ansvar utenfor kontrakt ${ }^{73}$ (foreligger det brudd på standarden om god meglerskikk vil det fortsatt være snakk om et erstatningsansvar i kontrakt ettersom den aktuelle bestemmelsen om god meglerskikk i eiendomsmeglingsloven supplerer oppdragsavtalen).

I det følgende skal det redegjøres for konsekvensen av brudd på undersøkelses- og informasjonsplikten som følger av god meglerskikk standarden.

\subsubsection{Ansvarsgrunnlag}

Det er forskjellig ansvarsgrunnlag avhengig av om det megler eller meglerforetaket som stilles til ansvar. Stilles meglerforetaket ansvarlig er det arbeidsgiveransvaret og § 2-1 i lov om skadeserstatning (av 13.juni. Nr. 26. 1969) som er ansvarsgrunnlaget (oppdragsgiveransvar og kontraktsmedhjelperansvar kan også være ansvarsgrunnlag her ${ }^{74}$ ). Meglerforetaket hefter objektivt, uavhengig egen skyld, for meglerens uforsvarlige handlinger i foretakets tjeneste ${ }^{75}$. Dette innebærer at megleren minst må ha opptrådt uaktsomt for at foretaket skal pålegges erstatningsansvar. Hefter foretaket for meglerens feil kan erstatningskravet reises mot megleren og foretaket som solidarisk ansvarlige, jf. skadeserstatningsloven (skl.) § 5-3 nr.1.

\footnotetext{
${ }^{71}$ Lødrup (2009) s. 53-54, Nygård (2000) s. 5-6.

${ }^{72}$ Rt. 1995 s. 1350 og Rt. 2005 s. 870.

${ }^{73}$ Rt. 2005 s. 870.

${ }^{74}$ Rosén og Torsteinsen (2008) s. 522.

${ }^{75}$ Nygård (2000) s. 216.
} 
Dersom megleren stilles erstatningsansvarlig, er det et ansvar på subjektivt grunnlag, også kalt culpaansvar eller skyldansvar. For å få tilkjent erstatning er det derfor krav om at megler har utvist skyld ${ }^{76}$. Skyldkravet er uaktsomhet ${ }^{77}$. Etter dette er det klart at megleren må ha utvist uaktsomhet ved utførelsen av megleroppdraget både i forhold til foretakets og meglers ansvarsgrunnlag.

Høyesterett uttaler seg som følger i Rt. 1995 s. $1350^{78}$ :

"Det gjelder i utgangspunktet et strengt, ulovfestet uaktsomhetsansvar for profesjonsutøvere. Likevel er det et visst spillerom før atferd som kan kritiseres, må anses som erstatningsbetingende uaktsomhet.

Når det spesielt gjelder kravene til eiendomsmeglere, gir lovgivningen en viss, men begrenset, veiledning for hva som skal rammes av den ulovfestede uaktsomhetsregelen."

Her refererer Høyesterett antakelig til eiendomsmeglingsloven, herunder god meglerskikk standarden, ettersom det må avgjøres ved en tolkning av den aktuelle bestemmelsen hvor stor veiledning lovgivningen gir $^{79}$. Brudd på god meglerskikk, i eml.§ 6-3 første ledd er imidlertid ikke i seg selv et tilstrekkelig grunnlag for profesjonsansvar overfor oppdragsgiveren ${ }^{80}$. Begrunnelsen er at det ikke er noe krav om subjektiv skyld for å konstatere brudd på normen om god meglerskikk (men subjektiv klander kan være et moment ved vurderingen av om en opptreden er i strid med god meglerskikk) ${ }^{81}$. Eml. $§ 6-3$ første ledd er som nevnt dessuten vag og er en dynamisk rettslig standard. Når bestemmelsen i seg selv ikke gir utstrakt veiledning må man søke veiledning i alminnelig erstatningsrett ${ }^{82}$.

\footnotetext{
${ }^{76}$ Bergsåker (2008) s. 210.

${ }^{77}$ Nygård (2000) s. 173.

${ }^{78}$ Flere dommer om profesjonsansvar viser til denne Høyesterettsdommen, bl.a. Rt. 1996 s. 407, Rt. 1999 s. 408, Rt. 2003 s. 400 og LG 2002 s. 1033.

${ }^{79}$ Rosén og Torsteinsen (2008) s. 527.

${ }^{80}$ Bergsåker (2008) s. 211.

${ }^{81}$ Bergsåker (2008) s. 103.

${ }^{82}$ Rosén og Torsteinsen (2008) s. 527.
} 
Etter alminnelig erstatningsrett er det relevante vurderingstemaet om handlemåten var forsvarlig ${ }^{83}$. Nygård skriver at

"Grunndefinisjonen på skyld er at vedkomande på eit gitt tidspunkt skulle ha handla annleis i den situasjonen han var, slik at han dermed ville ha hindra eller ikkje iverksatt den årsaksfaktor han er påstått ansvarleg for." ${ }^{84}$.

Om plikten er brutt ved uaktsomhet må derfor vurderes konkret i hvert enkelt tilfelle fordi mange ulike situasjoner kan oppstå. Det kan derfor være vanskelig å si noe generelt om når plikten er brutt. Oppgavens punkt 3 kan imidlertid gi en viss veiledning. Dersom man etter en konkret vurdering har kommet til at megler har plikt til å kontrollere og/eller informere om finansieringen, og denne er brutt, vil man lett konstatere at uaktsomhet foreligger. Dersom finansieringen ikke undersøkes i det hele tatt, og den viser seg å ikke holde mål, og megleren i tillegg gir dårlig informasjon om risikoen ved dette må man legge til grunn at megler har vært uaktsom. Har megleren derimot foretatt alle de undersøkelser som er praktisk mulig å gjennomføre, og informert selgeren grundig om dette, og om den risikoen som foreligger, vil uaktsomhet være vanskelig å konstatere selv om finansieringen kommer til kort.

\subsection{2 Økonomisk tap og årsakssammenheng}

For å få tilkjent erstatning kreves det både at det foreligger et økonomisk tap og at det er en årsakssammenheng mellom tapet og meglers uaktsomhet. Kravet til årsakssammenheng og økonomisk tap henger derfor nært sammen.

Årsakssammenheng betyr at meglers forsømmelse må være årsaken til tapet. Tapet må kunne tilbakeføres til forhold som megleren er ansvarlig for. Her vil det si at tapet må ha oppstått fordi megler ikke kontrollerte og informerte om kjøpers finansiering. Dersom tapet

\footnotetext{
${ }^{83}$ Nygård (2000) s. 170.

${ }^{84}$ Nygård (2000) s. 172.
} 
hadde oppstått uansett om megleren hadde kontrollert og informert eller ikke, kan ikke megleren holdes ansvarlig. Hadde derimot tapet vært unngått om megleren hadde kontrollert finansieringen, kan man kreve erstatning.

Ved vurderingen av årsakssammenhengen må man ofte se på alternative hendelsesforløp for å finne ut av om megleren er ansvarlig. Spørsmålet er hva som hadde skjedd dersom megleren hadde kontrollert finansieringen. I dette tilfellet er det flere mulige resultater av selve finansieringsundersøkelsen. Her holder jeg meg til tre mulige utfall, men det kan tenkes mer nyanserte resultat. Det ene tenkelige resultatet er at finansieringen forblir ubekreftet. Det andre er at finansieringen blir bekreftet men fremstår som usikker. Et tredje alternativ er at finansieringen fremstår som sikker etter en kontroll. Det er kun hvis selger ikke hadde akseptert et bud hvor finansieringen var ubekreftet eller bekreftet men usikker, selv om megler hadde informert om dette, at vilkåret om årsakssammenheng er oppfylt. Problemer kan imidlertid oppstå dersom selgeren ikke kan vise at det var andre budgivere eller interessenter som var villige til å betale mer enn det som ble betalt ved dekningssalget. Om andre budgivere hadde sikrere finansiering kan også være uvisst og dermed skape problemer for kartleggingen av alternative hendelsesforløp.

Dette viser at det er flere omstendigheter som kan spille inn. Ettersom det også kan være flere årsaker til selgerens økonomiske tap må hver situasjon bedømmes konkret. Utover de retningslinjer som er trukket her kan det derfor ikke sies noe mer generelt om årsakssammenheng og finansieringskontroll.

\subsubsection{Grensen - upåregnelig eller avledet tap}

Økonomisk tap kan være så mangt. Spørsmålet er derfor hvilke tap som kan kreves erstattet. Grensen går mot tap som er upåregnelige eller avledete ${ }^{85}$. Dette er tap som i sin

\footnotetext{
${ }^{85}$ Nygård (2000) s. 343-345.
} 
art er uventet, eller er så stort i omfang at det er upåregnelig ${ }^{86}$. Gjennom disse begrensningene tas det hensyn til eiendomsmegleren og/eller eiendomsmeglingsforetaket.

Det følger av mindretallet i LG 2002-1033 at selger ikke kan kreve megler for hele den kjøpesummen som ikke blir betalt. Selger kan nemlig ikke kreve erstatning for den positive kontraktsinteresse overfor megler med grunnlag i den kontrakten selger har med kjøper. Kravet som kan fremsettes er ikke nødvendigvis identisk med det kravet som kunne vært rettet mot kjøper. Et krav mot megler må bygge på at selgerne er påført et tap ved at megleren har opptrådt erstatningsbetingende uaktsomt.

Tap som kan oppstå for selger når kjøpers finansiering svikter, og som følge av at megler har forsømt kontroll- og undersøkelsesplikten, kan blant annet tenkes å være tap ved dekningssalg, merutgifter knyttet til dekningssalget, tapt renteavkastning av kjøpesummen som skulle vært betalt, og forsinkelsesrenter ved et eventuelt nytt boligkjøp hvor man er avhengig av oppgjør for eksisterende bolig.

Ved et dekningssalg selger man eiendommen på nytt på et senere tidspunkt enn det opprinnelige kjøpet. Markedet kan ha hatt en nedgang i denne tidsperioden som medfører at man får mindre betalt enn i første salgsrunde. En slik negativ utvikling fører til et økonomisk tap for selgeren. Spørsmålet er hvem som skal ha risikoen for markedsutviklingen i denne perioden. Når svikten i den opprinnelige kjøpers finansiering kunne vært avdekket ved en kontroll, og vært opplyst om til selger, kunne man unngått å inngå avtale med denne kjøperen eller kommet seg raskt ut av avtalen for eksempel grunnet misligholdt forskudd. Megleren må i så fall ha risikoen for et eventuelt tap ved dekningssalg.

Det er normalt at det påløper ekstrautgifter til blant annet markedsføring/annonsering, nye visninger og lignende når man gjennomfører et dekningssalg. Utgiftene bør kunne kreves

\footnotetext{
${ }^{86}$ Rosén og Torsteinsen (2008) s. 563.
} 
av megler dersom man ikke ville inngått avtale med denne kjøperen hvis megler hadde kontrollert og informert om kjøperens finansiering. Å prøve å kreve utgiftene av en allerede ikke-søkedyktig kjøper er uhensiktsmessig. I følge Rosén og Torsteinsen "skal det nok atskillig til før det kan bli tale om begrensning av ansvaret ut fra adekvansbetraktninger" dersom det pådras utgifter som eiendomsmegleren er ansvarlig for ${ }^{87}$.

Dersom finansieringsproblemene fører til at man selv kommer i forsinkelse med betalingen av sin nye bolig kan man få ekstrautgifter på grunn av forsinkelsesbeføyelser. Utgiftene vil i tilfelle være en direkte konsekvens av at den første kjøperen ikke kunne gjøre opp for seg. Dersom dette kunne vært unngått ved at megleren hadde kontrollert og informert om finansieringen vil han måtte stå til ansvar for slike utgifter.

Tapt renteavkastning på den kjøpesummen man opprinnelig kunne oppnådd fra en alternativ kjøper må også kunne kreves, dersom man ikke hadde tenkt å plassere pengene videre, da dette vil være et økonomisk tap som følge av misligholdet. Det samme gjelder for morarenter eller forsinkelsesrenter av den kjøpesummen man opprinnelig kunne fått. Morarenter må derfor kunne kreves fra den opprinnelige kjøpesummen skulle vært betalt og frem til oppgjøret kommer i dekningssalget.

Et eksempel på et økonomisk tap som er for avledet kan for eksempel være et tap som har oppstått ved at selger har hatt ekstrautgifter ved flyttingen fordi han ikke fikk benyttet seg av et flyttebyrå med kampanjetilbud i en avgrenset tidsperiode. Et annet eksempel kan være hvor det oppstår en rekke av mislighold som medfører tap. Dette kan skje dersom meglers oppdragsgiver, der denne er kjøper i et annet forhold, kommer i mislighold overfor sin selger fordi hans egen kjøper ikke kan gjøre opp for seg. Da kan det oppstå et tap også for selgers selger, som igjen kan føre til en rekke av mislighold. I så tilfelle må man sette en grense et sted. Etter min mening er det tapet som oppstår for selgers selger for avledet, slik

\footnotetext{
${ }^{87}$ Rosén og Torsteinsen (2008) s. 563.
} 
at megler ikke kan holdes ansvarlig for dette eller andre tap som måtte oppstå lengre ut i misligholdsrekken.

\subsection{Nedsettelse av meglers vederlag}

Etter eml.§ 7-7 kan vederlaget kreves nedsatt eller bortfalt dersom det foreligger en "ikke ubetydelig pliktforsømmelse" fra meglers side. For at vederlaget skal settes ned, er det ikke et krav at megler har opptrådt klanderverdig. Nedsettelse kan derfor kreves på objektivt grunnlag $^{88}$. Noe krav om økonomisk tap er det heller ikke ${ }^{89}$. I følge forarbeidene er det et minimumskrav at meglers plikter er tilsidesatt mer enn det rent bagatellmessige ${ }^{90}$. Dette viser at det vil være lettere å få nedsatt meglerens vederlag enn å få erstatning på grunn av brudd på standarden om god meglerskikk, ettersom det er strengere vilkår for å få tilkjent erstatning.

Dersom man ikke får erstatning kan man i stedet kreve nedsettelse av meglers vederlag. Det kan imidlertid spørres om man kan kreve nedsettelse i tillegg til erstatning. Det er ingen direkte og automatisk sammenheng mellom oppfyllelse av et krav på erstatning og nedsettelse av meglers vederlag ${ }^{91}$. Det er derfor ikke noe i veien for at man både får erstatning og får nedsatt meglers vederlag helt eller delvis. Om det foreligger et økonomisk tap er riktignok et moment $i$ vurderingen av om man skal nedsette meglers vederlag ${ }^{92}$. Dessuten kan dette tapet reduseres eller anses fullstendig kompensert ved at erstatning eventuelt ytes. Hvorvidt man får erstatning vil derfor ha betydning for bedømmelsen av om vederlaget skal nedsettes. Likevel er det etter min mening ikke noe i veien for at man kan få begge deler.

\footnotetext{
${ }^{88}$ NOU 1987:14 s. 89.

${ }^{89}$ NOU 2006:1 s. 110.

${ }^{90}$ Ibid.

${ }^{91}$ Rosén og Torsteinsen (2008) s. 511.

${ }^{92}$ Rosén og Torsteinsen (2008) s. 504.
} 
Hva som nærmere bestemt ligger i "ikke ubetydelig pliktforsømmelse" er uklart. Et brudd på en kontroll- og informasjonsplikt om kjøpers finansiering er imidlertid et alvorlig pliktbrudd da plikten skal sikre oppgjør, som er hovedytelsen i avtalen mellom selger og kjøper. Brytes plikten anses megler i tillegg å ha opptrådt uaktsomt. Utgangspunktet for drøftelsen av ubetydeligheten må derfor knytte seg til omfanget av tapet. Dette konstateres også ved at det blant annet skal vurderes hvilken økonomisk og annen ulempe skadelidte har hatt på grunn av meglerens pliktbrudd ${ }^{93}$. Er tapet stort, vil pliktforsømmelsen være mer betydelig enn om tapet er lite. Dette stadfestes også av Rosén og Torsteinsen som skriver at prosessøkonomiske hensyn taler "... for at man generelt bør være varsom med å tilkjenne prisavslag som utgjør mindre enn fem til ti prosent av vederlaget, da det ofte vil tyde på at pliktforsømmelsen må anses for å være ubetydelig" ${ }^{94}$. Når man etter dette eventuelt har fastslått at det er grunnlag for å sette ned vederlaget, må det avgjøres hvor mye vederlaget skal nedsettes.

\subsection{Oppsummering konsekvensene av pliktbrudd}

Konsekvenser av pliktbrudd kan etter dette blant annet være at meglerens vederlag blir nedsatt helt eller delvis, og/eller at megler blir erstatningsansvarlig overfor selger.

For begge ansvarsgrunnlagene ved erstatning, skyldansvar og arbeidsgiveransvar, kreves det at megleren, der han har plikt til å kontrollere og informere om finansieringen, uaktsomt har forsømt å gjøre dette. Det skal nok som nevnt lite til for å konstatere slik uaktsomhet. I tillegg kreves det at det foreligger et påregnelig økonomisk tap for å få tilkjent erstatning, og at tapet skyldes meglers pliktforsømmelse. For nedsettelse av vederlaget er det derimot ikke krav om subjektiv skyld eller økonomisk tap, som ved erstatning. Derimot må konsekvensen av bruddet være mer enn det rent bagatellmessige.

\footnotetext{
${ }^{93}$ NOU 1987:14 s. 88 annen spalte.

${ }^{94}$ Rosén og Torsteinsen (2008) s. 507.
} 
Dette viser at det er vanskeligere å få tilkjent erstatning enn å få vederlaget nedsatt. Det er ikke noe til hinder for at man både får tilkjent erstatning og nedsatt vederlaget helt eller delvis. Dersom erstatning tilkjennes, kan det derimot være et moment som medfører at det kan være vanskelig å få vederlaget nedsatt i tillegg.

\section{Oppsummering}

Gjeldende rett er at megleren i en viss grad har plikt til å kontrollere kjøpers finansiering dersom særlige omstendigheter tilsier det. Megleren har dessuten en informasjonsplikt der finansieringen fremstår som usikker.

Ettersom det må foreligge særlige omstendigheter for at megler skal ha en plikt mener jeg at man ikke kan snu hovedregelen, slik Rosén og Torsteinsen gjør ${ }^{95}$, og si at det er en generell undersøkelsesplikt. Dette er det etter min mening ikke holdepunkter for i gjeldende rett, og det burde i så tilfelle kommet klart frem av rettskildene. Utgangspunktet må derfor etter min mening fortsatt være at megler ikke har noen alminnelig plikt til å kontrollere kjøpers finansiering. Hvert tilfelle må imidlertid vurderes konkret for å avgjøre om det foreligger slike særlige omstendigheter, som etter en helhetsvurdering taler for at megler har en undersøkelses- og informasjonsplikt. Har megler i et konkret tilfelle en kontroll- og undersøkelsesplikt, vil omfanget av plikten bero på omstendighetene og på hva som er praktisk mulig å kontrollere og fremskaffe av informasjon.

Brytes meglers plikt, kan konsekvensen bli at hans vederlag settes ned eller at han blir erstatningsansvarlig for selgerens eventuelle tap. Dette innebærer at megler, for å unngå økonomisk ansvar, derfor bør gjøre det han kan for å kontrollere kjøpers finansielle stilling og samtidig holde kjøperen informert om risikoen ved finansieringen.

\footnotetext{
${ }^{95}$ Rosén og Torsteinsen (2008) s. 352 og 548.
} 
Gjennomgangen av rettskildene viser at rettstilstanden har vært, og er, i bevegelse, mot en alminnelig plikt for megleren til å kontrollere finansieringen. Etter min mening er det likevel som nevnt for tidlig å snu hovedregelen. Min oppfatning er at gjeldende rett om meglers plikter knyttet til kjøpers finansiering bør fremgå av lovgivningen grunnet hensyn til forutberegnelighet for berørte parter. Dette er ikke i tilstrekkelig grad tilfellet i dag, og dagens rettstilstand burde ha fremgått tydeligere av rettskildene, særlig forarbeidene til den eiendomsmeglingsloven av 2007. Får man et utgangspunkt i fremtiden hvor megler har en generell kontroll- og undersøkelsesplikt bør dette derfor fremgå av rettskildene på en tydelig måte. En mulighet kan være å innta en paragraf tilsvarende eml.§ 6-7 (om meglers informasjonsplikt overfor kjøper) som regulerer meglers kontroll og informasjonsplikt overfor selgeren. 


\section{Doms - og avgjørelsesregister}

6.1 Høyesterett

- Rt. 2005 s. 870

- Rt. 1995 s. 1350

- Rt. 1993 s. 156

6.2 Lagmannsrett

- $\quad$ RG 2007 s. 1145

- $\quad$ RG 2004 s. 552

- LG 2002 s. 1033

- $\quad$ LB 1996 s. 317

\subsection{Tingrett}

- Dom fra Oslo tingrett av 8. januar 2009 (Krystallen)

6.4 Reklamasjonsnemnda for eiendomsmeglingstjenester

- $1994 / 63$

- $1997 / 16$

- $1999 / 8$

- $2000 / 100$

- $2001 / 75$

- $2002 / 44$

- $2003 / 126$

- $2003 / 138$

- $2004 / 82$

- $2005 / 19$

- $2005 / 122$

- $2005 / 124$

- $2006 / 343$ 
- $2007 / 102$

- $2008 / 81$

- $2008 / 109$

- $2008 / 147$

- $2008 / 188$

- $2009 / 7$

\subsection{Disiplinærnemnden for advokater}

- ADA-2006-D103

\section{Litteratur}

\subsection{Bøker}

- Bergsåker, Trygve. Eiendomsmegling - omsorgsplikt og god meglerskikk. Med et spesialstudium av salg ved budgivningskonkurranse. Avhandling (dr.juris) Universitetet i Oslo, 2008.

- Bråthen, Tore og Solli, Margrethe Røse (Red.). Larebok i praktisk eiendomsmegling, Del 1. 3.utg. Oslo, 2008.

- Bråthen, Tore og Solli, Margrethe Røse (Red.). Larebok i praktisk eiendomsmegling, Del 2. 3.utg. Oslo, 2008.

- Gisle, Jon ... [et al.], Jusleksikon. 3.utg. Oslo, 2007.

- Lødrup, Peter og Kjelland, Morten. Larebok i erstatningsrett. 6.utg. Oslo, 2009.

- Nygård, Nils. Skade og ansvar. 5.utg. Bergen, 2000.

- Rosén, Karl og Torsteinsen, Dag Henden. Eiendomsmegling-rettslige spørsmål. 1.utg. Oslo, 2005.

- Rosén, Karl og Torsteinsen, Dag Henden. Eiendomsmegling - rettslige spørsmål. 2.utg. Oslo, 2008. 


\subsection{Internettsider}

- $\quad \underline{w w}$.eiendomsmeglingsnemnda.no

- www.advokatforeningen.no

\section{Forarbeid-og lovregister}

\subsection{Lover}

- Lov om eiendomsmegling av 29.juni. Nr.73. 2007 (eml.)

- Lov om avtalar med forbrukar om oppføring av ny bustad m.m. av 13.juni. Nr. 43. 1997 (bustaoppfl.)

- Lov om avhenging av fast eigedom av 3.juli. Nr. 93.1992 (avhl.)

- Lov om skadeserstatning av 13.juni. Nr. 26. 1969 (skl.)

\subsection{Forarbeider}

- Ot.prp.nr. 16 (2006-2007)

- Ot.prp.nr. 59 (1988-1989)

- NOU 2006:1

- $\quad$ NOU 1987:14 